Portland State University

PDXScholar

$5-1-1970$

\title{
Nutritional requirements for protease production by Pseudomonas aeruginosa, Ps-1C
}

Richard Myer Avedovech

Portland State University

Follow this and additional works at: https://pdxscholar.library.pdx.edu/open_access_etds Let us know how access to this document benefits you.

\section{Recommended Citation}

Avedovech, Richard Myer, "Nutritional requirements for protease production by Pseudomonas aeruginosa, Ps-1C" (1970). Dissertations and Theses. Paper 629.

https://doi.org/10.15760/etd.629

This Thesis is brought to you for free and open access. It has been accepted for inclusion in Dissertations and Theses by an authorized administrator of PDXScholar. Please contact us if we can make this document more accessible: pdxscholar@pdx.edu. 
AN ABSTRAC OF THE THESTS Of Rachird Mat Avedovech Jx, for the Master of Science in Biology presented May $22,3970$.

Title: Nitritional Requirements for Protease Production by Pseudononas aevurinosa, Ps- Io

APROVEO BY HEMBERS OF THE THESTS COMHTTER:

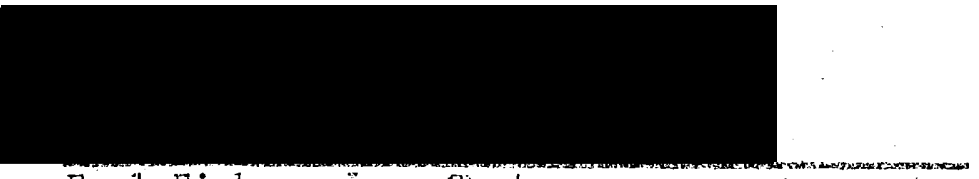
Eaxl Fister, Jro, Chaiman

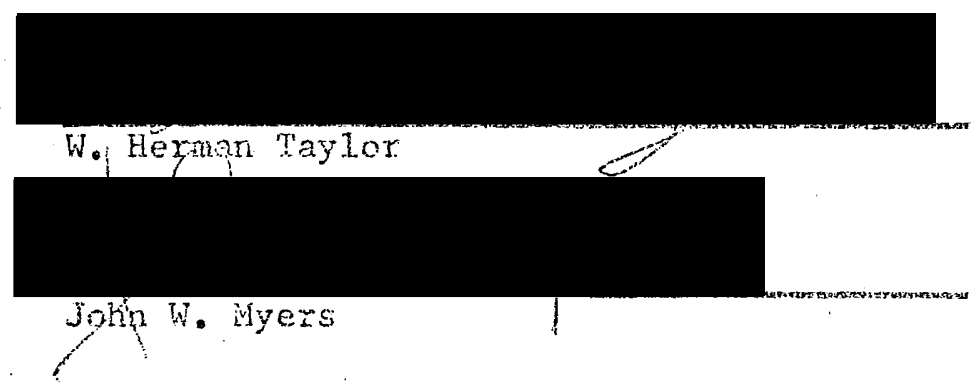

Pseudomonas aeruginosa esulc produces an extracellular proteolytic enzye which from prelininary studies appears to be inducible, and responsible for comeal destruction in injured eyes.

In the present study the rutritional requirements for this bacterium to produce the proteolytic enryme(s) were investigated. Preliminary studies indicated that proteose peptone offered the required nutrients for good enzyme production, The separation of the components of proteose peptone by Sephadex G-10 and Sephadex G-75 descending column chromatography was undertaken to illucidate the nutritional reçuirenents.

It vas also noted that casamino actes hydrolysaie senved as a good 
substrate for Eseudomonas aeruginosa to produce this enzyme. The separation of amino acid groups was undertaken using paper and Geon electrophoresis and various types of thin layer chromatography. The three anino acids found to be required for eod protease production vere, phenylalauine, isoleucine, and valine in their respective concentrations of $0.5 \mathrm{mg} / \mathrm{m} 1,1.0 \mathrm{mg} / \mathrm{m} 1$, and $2.0 \mathrm{mg} / \mathrm{m} 1$. Isoleucine was found to be inhbiting at higher concentrations. Sextrose also inhibited protease production, but not growth, at concentrations greater than $0.05 \%$. Divalent metal ions in varying coticentrations were tested as nutritional requirements for enzyme proluction. Magnesium ion provided very good enzymatic activity at a concentration of 0.01 , whereas cobalt, copper, caicium and zinc ions did not allow appreciable enzyme activity and even in some cases were inhibitive. 
NUTRITTONAE REGUTRENENS FOR PROTEASE PFODUCTIOA RY

PSEUDOMORAS AERUGTOSA, PS-10

by

RICHARD IYER AVEDOVECE, JR,

A thesis submitted in partial fulfillment of the requirements for the degree of

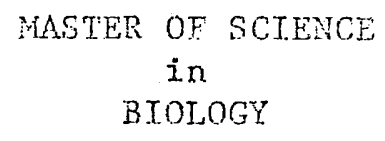

in

BIOLOGY

Portland State University

1970 
TO THE OFFJCE OF GRADUATE STUDIES:

The members of the Comittee approve the thesis of

Richard Hyer Avedovech, Jr, presented May 21, 1970.

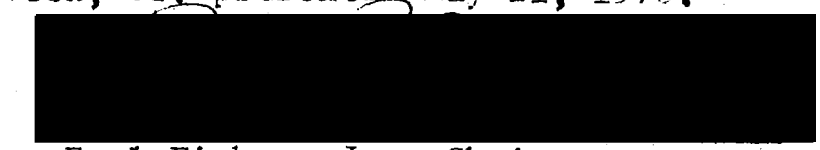

Earl Fisher, Jr., Chairman

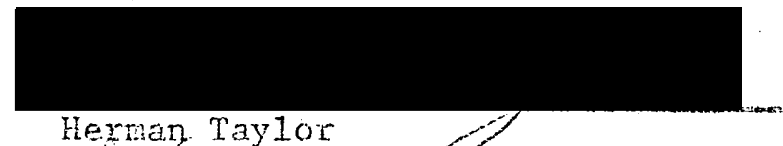

Heyman Taylor

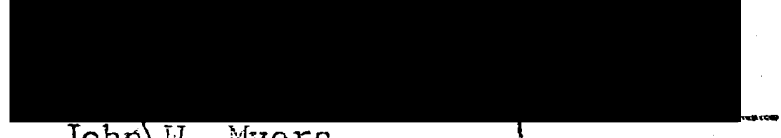

John W. Myers

\section{APPROVES:?}

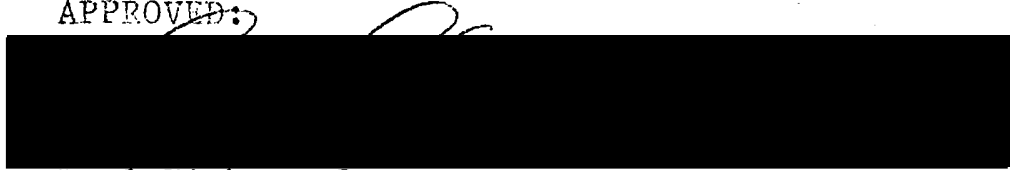

Earl Fisher, Jr, head, Department of Biology

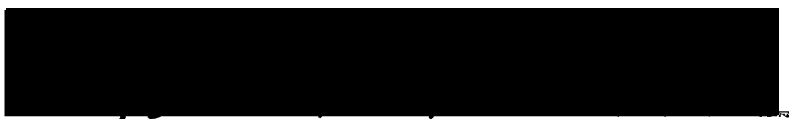

Frayk L. Roberts, Acting Dean of Graduate Studies

May 2I, 1970 


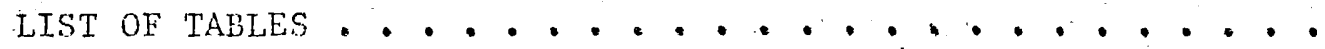

Definition of Terms... . , . . . . . . . . . . . .

Background . . . . . . . . . . . . . . . . .

Clostridial Collagenase

Other Nutritional Studies

Role of Amino Acids. . . . . . . . . . . . . .

Inhibition . . . . . . . . . . . . . . . . .

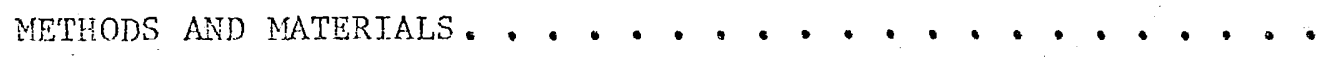

Organism . . . . . . . . . . . . . . . . .

Starter Cultures . . . . . . . . . . . . . .

Culture Nedia. . . . . . . . . . . . . . . .

Protenlytic Assay for Ps-1C Protease . . . . . . .

Glucose Inhibition Deternination . . . . . . . . . .

Proteose Peptone Analysis. . . . . . . . . . . . .

Preparation of Proteose Peptone for Substrate Testing

Casamino Acid Aralysis . . . . . . . . . . . .

Preparation of Casamino Aclds

for Substrate Testing

Paper electrophoresis of Casamino 

Determiration of the Rffect of $10^{-4} \%$
Casamino Acid Dialysate for
Substrate Testing
Geon Electrophoresis of Casamino Acid Dialysate

Chromatography of Casamino Acids

Specific Amino Acid Analysis . . . . . . . .

Amino Acid Combinations Tested as

Nutritional Reciuirements

Amino Acid Concentration pequirement

Deternination of Dextrose Concentration

and Repression . . , , . .., , , , , ,

Growth Curves. . . . . . . . . , . ..,

Growth Curve Vs, Optical Density at $\lambda 660 \mathrm{~nm}$

Growth and Protease Production

Versus Time

Divalent Metal Ion Concentraton

Réquirement .........., ......

Glucose Inhibition Determination . ........, .

Proteose Peptore Analysis . . . . . . . . . .

Casamino Acid Analysis . . . . . . . . . .

Amino Acid Combinations Tested as

Substrate for Ps-10 Protease

Production

Divalent Metal Ion Pequirenent . . . . . . . .

Growth Curves. . . . . . . . . . . . . .

Growth Curve of Eseudomones aerurinosa

Ps-1C as Correlated to Optical Density

at Wavelength $660 \mathrm{~nm}$

Groyth and Protesse Production. Vs. Time 


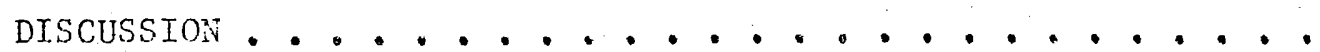

Glucose Inhibition of Protease Production. . . . . .

Proteóse Peptone Analysis . . . . . . . . . . .

Amino Acid Aralysis . . . . . . . . . . . . . .

Divalent Metal Ion Recuirement . . . . . . . . . . . .

Enzyme Production Versus Growth . . . . . . . . . . 
I Hershey's M-9 Growth Medium . • • . • . . •

II Chromatography Systens Used on Casamino Acids . . •

IIJ Growth Curve of Pseudomonas aerurinosa versus optical Derisity at Wavelength $660 \mathrm{~nm} \cdot$. . . . .

IV Casamino Acid Dialysate Substrate Experiment • • •

V Substrate Tests of Casamino Acids, Geon Electrophoresis Pools...................

VI. Substrate Tests of Casamino Acids, Geon Electrophoresis II, Sephadex G10 Pools . . . . . . .

VII Substrate Tests of General Amino Acid Groups for Enzyme Production . . . . . . . . . . .

VIII Amino Acids Combinations-I Tested as Nutritional

$$
\text { Requirements for Ps-1C Protease Production . • }
$$

IX Amino Acid Combinations-II Tested as Nutritional.

Requirements for Psm1C Protease Production • *

$X$ Arino Acid Combinations-III Tested as Nutritional

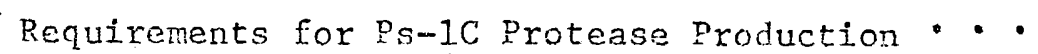

XI Amino Acid Combinations-IV Iested as Nutritional

$$
\text { Requirements for Ps-1C Protease Production... }
$$

XII Isoleucine Concentration Requirement for Ps-1C

$$
\text { Protease Production . . . . . . . . . }
$$


XIII Phenylalanine Concentration Requirement for Ps-1C

$$
\text { Protease Production . . . . . . . . }
$$

XIV Valine Concentration Requirement for PS-1C Protease Production . . . . . . . . . . .

XV Tests for Inhibition by Excess Required Amino Acid 


\section{LIST OF FIGURES}

FIGURE

PAGE

1. Schematic of the breakdom of casamino acids for: detemination of amino acid reguirements for Ps -1 protease production . . . . . . .

2 Dextrose concentration deternination for the best Ps-1C protease prodution . . . . . . .

3a Sephadex G10 column chronatography of $10 \%$ proteose peptone . . . . . . . . . . . . *

3b Sephadex G75 colum chromatography of proteose peptone, Sephadex G10, Pool I . . . . . .

3c Sephadex G75 column chromatosraphy of $10 \%$ proteose peptone . . . . . . . . . . . . . .

3d Sephadex G10 colunn chromatography of $10 \%$ proteose peptone, sephadex G75, pooI II. . . . .

4 Geon electrophoresis of casamino acids using a 0.05 phosphate buffer, pH 6.02 . . . .

5 Standard spot-o-gram for casamino acids, Geon electrophoresis II, sephadex G10 fractions . .

6 One dimensional paper chronatography of the five pools from sephadex G10 treatrent of casarino acids, Geon electrovhoresis pool Ir . . . . . .

7 One dimensional thin layer chronatography of casanino acids, Geon electrophoresis TI, sephadex G10 II 
8 One dimensional thin layer chromatography of casamino - acids, Geon electrophoresis II, sephadex G10 II • •

9 One dimensional thin layer chromatography of casanino acids, Geon electrophoresis IJ, sephadex G10 II • •

10 Two dimensional, thin layer chromatography of casamino acids, Geon electrophorsis II, sephadex G10 II . • 46

11 Two dimensional thin layer chronatography of casanino acids, Geon electrophoresis II, sephader G10 II . .

12. Two dimensional thin layer chromatography of casanino acids, Geon electrophoresis II, sephadex G10, pool II . . . . . . . . . . . . 48

13 Comparison of metal ion concentration requirenents for Ps-1C protease production ..........

14 Growth versus optical density at wavelength $660 \mathrm{~nm}$, for Pseudomonas aeruginosa, Ps-1C in nutrient broth-yeast extract:. . . . . . ...... 60

15 Growth and protease production versus time in Pseudomonas aeruginosa, Ps-1C . . . . . ... 


\section{INTRODUCTION}

The purpose of this work is to determine some of the nutritional requirements for the bacterium Pseudomonas aeruginosa to produce a proteolytic enzyme(s) which is apparently inducible, and possibly has collagenase activity.

\section{Definition of Terms}

Proteolytic enzynes or proteinases have been defined as enzymes that can hydrolyze a peptide bond when it is situated within a large molecule, (Thimann, 1963). Proteolytic enzymes include the serine proteinases such as chymotrypsin, trypsin, elastase, and thrombin; the cysteine proteinases such as papain, ficin, and bromelain; the metal containing peptidases such as the aminopeptidases and carboxypeptidases; and peptidases active at acid pH's such as pepsin and remin, (Bender and Kezdy, 1965). The enzyme of this study probably falls under the category of a metal containing protease.

An operational definition or classification of an extracellular enzyme is that it must demonstrate that the enzyme occurs in the medium, separated from the cells, and that the appearance of the enzyme in the medium does not depend upon irreversible damage to the cell structure. (Po1lock, 1962).

Induced enzyme formation is when increases in enzyme activity correspond to increases in the amount of an enzymically active protein, after exposure of the cells with the specific substrate or substances chemically closely related to the subetrate. Specific inducer molecule(s) 
is shown to be necessary at some stage in the chain of events leading to formation of a particular enzyme.

Maschmann (1938) proposed the name collagenase for the extracellular gelatin-splitting enzyne. However, Jennison (1945) found several species of bacteria which cleave gelatin but are unable to attack collagen in the form of untreated beef tendon (tendo Achillis), and finely fibrous, highly purified collagen from steer hide; therefore he restricts the name collagenase to the "collagen-splitting" enzyme.

Background

Narayanan, Devi, and Menon (1953) tested various isolates of Vibrio cholera and other organisms including a pseudomonad (Pseudomonas pyocyanea) for the enzymatic activity of collagenase, elastinase, and mucinase. The collagen substrate was buffalo tendo Achillis. It was noted that the pseudomonad had appreciable collagenase and elastinase activity.

In 1958, Fisher and Allen (1958) determined that cell-free extracts of Pseudononas aeruginosa produced corneal ulcers. A proteolytic enzyme fraction was obtained and partially purified which entanced both proteolytic activity and severe corneal destruction of rabbit eyes. It was inferred that growth of the organisms in the presence of organic materials, probably proteins, is essential for proteolytic enzyme production in corneal destruction.

Neither comeal destructive factor nor protease enzyme activity could be detected when the organism was grown in a synthetic medium.

- This suggests that the protease is an adaptive (inducible) enzyme 
requiring the presence of an appropriate protein substrate before the enzyme is operative.

Later, Shoellnann and Fisher (1966) provided evidence that this enzyme from Pseudomonas aeruginosa which nay be responsible for the corneal damage is probably a collagenase. It is known that in clostridial collagenase, only the amino acid sequence of the general structure (amino group)-proline-r-glycine-proline-(carboxyl group) are susceptible to enzyme hydrolysis by cleavage of the $r-g l y$ bond. A synthetic substrate of carbobenzocy-gly-pro-gly-g1ympro-alanine was used since if a collagenase is present this hexapeptide should be split at the gly-gly- bond forming cbz-gly-pro-gly-/ and gly-pro-alanine. Silica gel thin layer chromatography demonstrated that these expected peptidles did occur. Parallel experiments with the collagenase from Clostridium histolyticum also cleaved the hexapeptide at the identical bond. Clostridial Collagenase. Using hide powder disintegration as a general indicator for collagenase action it was determined that enzymes produced by various clostridial species which affect hide powder is not related to pathogenjicity but possibly is associated with muscle destruction, (Evans, 1948).

Thimann (1963) states that the collagenase of Clostridium histolyticum is the most active of all collagenases, and is activated both by cysteine and by $\mathrm{FeSO}_{4}$. Also that there are several aerobes that have proteinases that are inhibited by cysteine but activated by $\mathrm{Fe}^{+1}$ or by cysteine plus $\mathrm{Fe}^{++}$. However it is now known that Clostridiun histolyticum forms at least two physicochemically and enzymically distinct extracellu]ar proteinases, one of which can be regarded as a 
specific collagenase which is not activated by $\mathrm{Fe}^{++}$and cysteine, (Pollock, 1962). This differs from the proteinases studied by kochalaty and Krejci (1948).

The k-toxin of clostridium velchil is specific for collagen and gelatin which has a high content of proline and hydroxyproline. However the narrow specificity of collagenase does not appear to be comected with these amino acids eince it does not seem to have prolidases nor prolinase activity. (Bidwe11, van Heyningen, and Charlwood, 1948). Bjdwell (1948) also noted that "true" collagenase began to be unstable in the cold at pil $8.5-9.0$ and was completely destroyed at pH 10.3. Warner temperatures accelerated the destruction.

It has been shown that the collagenase from Clostridium histolyticum requires $\mathrm{Ca}^{++}$for activation. This requixement has been tested by the removal of metal ions through dialysis and by treatment. with the chelating agent Na-EDTA which inactivates the enzyme. Complete enzyme activity is restored by adding back $\mathrm{Ca}^{++}$, whereas $\mathrm{Mg}^{++}$did not activate nor inhibit the enzyme. It appears that the $\mathrm{Ca}^{++}$is required for collagenase to be able to adsorb to a suspension of ichthyocol. (Gallop, Seifter, and Meilman, 1957)

There may be more than one metal involved in collagenase activity. Seifter, Gallop, Klein, and Meilman (1959) decermined that the purified enzyme is inhibited by sulfhydryl-containing agents, where the effect of these compounds seem to be on a non-calcium metal componenet of collagenase.

Mandl, Keller, and Vanahan (1964) obtained from Clostridium histolyticum collagenase preparation two distinct collagenolytic enzyme fractions. Collagenase I will not actack unspecific substrate azocoll. . 
and has minimal activity against gelatin; is not associated with proteolytic activities of crude collagenase, and has a high specific rate of synthetic substrate hydrolysis. Collagenase II is equally free of nonspecific activities, but is very active against both azocoll and gelatin. Both enzymes require $\mathrm{Ca}^{++}$for stability as well as for activity. EDTA (ethylenediaminetetracetate) and exhaustive dialysis irreversibly inactivates the purified collagenase, but in the more stable crude form, they can be reactivated by addition of $\mathrm{Ca}^{++}$.

Other Nutritional Studies. Keen and Villians (1967) did a nutritional study on Pseudomonas 1 achrymang and its production of a constitutive extracellular protease which is involved with the pathogenicity of angular leaf spot on cucumbers. The bacterium requires an organic form of nitrogen for growth in culture. Bacteria grown on synthetic media supplemented with $0.5 \%$ concentration of gelatin, casein, peptone, or lactalbumin grew better than non-supplemented control cultures. Gelatin and peptone slightly stimulated protease production, whereas casein and lactalbumin resulted in little or no production. Growth rates were greater in aerated cultures that in non-aerated cultures and protease activities were considerably higher in the aerated cultures. There was no significant protease activity detected in cultures at $0.0 .1 \%$ glutamic acid, but activity did correlate to growth at glutamic acid concentrations between $0.05 \%$ and $0.2 \%$. At glutamic acid concentrations above $0.2 \%$, hovever, enzyme synthesis was apparently repressed. When bacteria were grown on a synthetic media with $0.2 \%$ glutanic acid and various concentrations of sucrose, grovth increased proportion-ally with sucrose concentration. At $10 \%$ sucrose with $0.2 \%$ glutamic acid, growth was highest, but protease production was lowest. When the media 
contained $1 \%$ glutamic acid, the maximu protease synthesis was attained at $0.2 \%$ sucrose concentration, whereas the grovth increased up to the $5 \%$ sucrose level.

No growth or enzyme synthesis was observed when solely inorganic nitrogen was supplied to the bacteria. In cultures supplied with $0.16 \%$ glutamic acid in combination with inorganic nitrogen, better growth occurred than when glutamic acid was supplied alone.

Bacterial growth was limited by vaxious concentratons of glutamic acid, inorganis nitrogen, or sucrose; but only glutanic acid indicated a consistent correlation with protedse production. However, high concentrations of slutamic acid apparently repressed enzyme production and the repression was more pronounced when glutanic acid was supplemented with sucrose or inorganic nitrogen. These facts suggest that rapid assimilation of carbon by the bacteria represses protease production and counteracts the stimulation of synthesis by organic nitrogen.

Apparently it is rather common for extracellular enzymes to require a divalent ion as was demonstrated earlier with the clostridial collagenase. Casa and Zimmerman (1969) determined that an extracellular protease from Strentococcus faecalis var. liguefacins requires $\mathrm{Zn}^{+1}$, for the secretion of this enzyme was inhibited by EDTA. If $\mathrm{Zn}^{++}$is added back within a 45 minutes period, then a fraction of the enzyme activity is restored. Various results indicate that the energy for this proteolytic enzyme synthesis is apparently from arginine which is also required to stiumlate proteolytic activity after 60 minutes of EDTA treatment.

The early works of Berger, Johnson, and peterson (1938 a,b) have 
shown that the four gram negative rods, E. coli. Proteus, sp.,

Pseudomonas Eluorescens, and Pseudomonas tumefaciens, produced peptidases which al1 were activated by $\mathrm{Mg}^{++}$.

Litchfield and Prescott (1.970) working with proteolytic enzyme production by Aeromonas proteolytica determined that the amino acids asparagine, histidine, glutamic acid, alanine and proline could individually support appreciable growth and enzyme synthesis. Asparagine and histidine, individually and as a mixture of the two, allowed good enzyme elaboration.

When glyceroi was present, there was a decrease in endopeptidase production. Glucose, sucrose, and acetate also caused a reduction in Enzyme synthesis, although growth was not enhanced.

When acid-hydrolyzed casein was used as the carbon, nitrogen and energy source, proteinase production was twice that obtained in $0.2 \%$ asparagine.

Marvin, et, al. (1969) isolated and purified an exoenzyme, which was bacteriolytic on Staphylococcus aureus, from Pseudononas aeruginosa. This enzyme is stabilized in the presence of $\mathrm{Mg}^{++}$, and acts as an endopeptidase on peptidoglycans with poly-glycine bridges.

\section{Role of Amino Acids}

Sometimes amino acid analogues can stimulate enzyme production, although the analogue will not be detected in purified enzyme samples, (Hammel and Zimmerman, 1966).

It has been shown with Pseudomonas aeruginosa that a number of amino acids can serve as a good nitrogen source and/or as a good carbon source. Kay and Gronlund (1969) observed that alanine, arginine, aspar- 
agine, aspartate, glutamate, glutamine, glycine, isoleucine, leucine, proline, serine, tryptophane, tyrosine, and valine were good nitrogen sources. Among those amino acids which served as good carbon souces were included isoleucine and valine. .

Norton and Sokatch (1966) working with the oxidation of D-and L-valine by enzymes of Pseudomonas aeruginosa deternined that Dovaline was oxidized directly to 2-oxo-isovalerate. L-valine was deaminated by transamination with 2-oxoglutarate, It was not possible to demonstrate either the direct oxidation of L-valine or the conversion of $L$ - to Di-valine.

Sokatch (1966) did labeling experinents which indicates that Pseudomonas aeruginosa catabolized DL-valine by oxidation to isobutyrate and propionate. Alanine formed during growth on DL-valine-4-4 $-\mathrm{C}^{14}$ was . labeled in carbons 1 and 3, which suggests the direct oxidation of propionate derived from the isopropyl carbons of valine to pyruyate for alanine biosynthesis.

\section{Inhibition}

Working with an acid proteinase from Pseudomonas aeruginosa, Morihara (1963) determined that most heavy metal ions and chelating agents would inactivate the enzyme. This indicates that a divalent ion nay be required. Also oxidizing agents inactivated the proteolytic activity, although sulfhydryl groups are not necessarily essential for enzymic activity.

For the proteolytic enzymes of Clostridium velchii, Bidwell (1950) determined that citrate strongly inhibiced the enzyre, and that there was no evidence for activation by $\mathrm{Ca}^{++}$or $\mathrm{Mg}_{\mathrm{g}}^{++}$. The enzyme was slightly 
inhibited by iodoacetic acid, and cyanide, and strongly inhibited by cysteine.

Five amino acids, isoleucine, leucine, phenylalanine, tryptophane, and valine, specifically and individually repressed the formation of the induced extracellular protease of Streptococcus faecalis var. Liquefaciens. The protease, nor synthesis of other enzynes, nor growth of the organism were adversely affected by the presence of these amino acids. It has also been noted by Sonkuti and Babel (1967) in their studies on Mucor pusillus that there is an inverse relationship between the amount of proteinase and the amount of glucoss present in the culture media.

Concerning the enzyme of this study, it has previously been demonstrated that this proteinase is inhibited by thiol groups, cysteine, glutathione, mercaptoacetate and mercaptoethanol. Sodium iodoacetate inhibits enzyme production while chelating agents greatly reduced enzymatic activity. This inhibition could not be relieved by the addition of various metal ions, (Fisher, 1960). 
METHODS AND MATERIALS

Orfanism

The organistn used in this study is Pseudomonas aeruginosa, Ps-1C, obtained from the stock cultures of Dr. E. Fisher, Jr., Portland State University Biology Department. This strain vas originally isolated by Dr. Fisher from a corneal infection of a patient at Tulane Yedical School. The Ps-1C strain has been steadily maintained on blood agar plates, Frepared from, whole sheep blood and Difco Bacto Blood Agar Base,

\section{Starter Cultures}

Starter cultures for various experiments incculated from a blood agar stock culture plate. One loop of Pseudomonas aeruginos Ps-1C was transferred into $50 \mathrm{mls}$ of sterile medium containing nutrient brothyeast extract in a $150 \mathrm{ml}$ Erlenmeyer flask stoppered with a cotton plus. This was then put on a Gyrotory Shaker, Model G-25, New Brunswick Scientific Co., for 12 - 18 hours, at $36-39^{\circ} \mathrm{C}$, and the shakex speed set at 6.5. At the and of the incubation tine the number of cells per ml of culture is determined by reading the optical density of the cuiture at $660 \mathrm{~nm}$ in a Gilford 2000 Automatic Spectrophotometer, and comparing the reading to a previously deternined plot of viable cells versus optical density at $660 \mathrm{~nm}$.

\section{Culture Media}

The conplete mediun was composed of dehydxated $0.8 \%(\mathrm{w} / \mathrm{v}$ ) nutrient broth, and $0.5 \%(\mathrm{w} / \mathrm{v})$ yeast extract. The corponents are dissolved and sterilized in an American Sterilizer Autoclave, Model 57 CR, for 15 minutes at $250^{\circ} \mathrm{C}$. These conditions were used consistently for the 
sterilization of all media and equipment used where sterilization vas required.

The synthetic salts medium used throughout this study was lershey's M-9 mininal salts nedium containing the salts listed in Table $I$, in which part A was mixed and sterilized as a unit, and in part $B$ the individual solutions were separately sterilized and then added aseptically to part $\mathrm{A}$.

\section{Proteolytic Assay for PS-1C Protcase}

The proteolytic activity was followed by means of a colorimetric procedure which depends on the enzymatic release of colored non-wrichloroacetic acid (TCA) precipitated products from a diazotized protein. The method of diazotization was essentially that of Tomarelli, Charney, and Harding (1949). The method of assay is essentially that of fisher and Allen (1958) with a slight modification.

The incubation mixture was composed of the following: $0.1 \mathrm{ml}$ sample to test for enzyne activity; $0.9 \mathrm{ml}$ distilled water; $0.5 \mathrm{~m} 1$ of $0.05 \mathrm{M}$ tris buffer (Tris (hydroxymethyl)aminomethane), $\mathrm{pH} 7.2$; and $0.5 \mathrm{ml}$ of $1 \%$ diazotized casein. This mixture was incubated in a water bath at $37^{\circ} \mathrm{C}$ for 10 minutes. The reaction was stopped by the addition of $5 \mathrm{ml}$. of 5\% TCA. The acidified mixture was filtered to remove the precipitated proteins and the color was intensified by adding $2.5 \mathrm{ml}$ of 0.5 $\mathrm{N} \mathrm{NaOH}$ to $2.5 \mathrm{ml}$ of filtrate. The optical density was read at wavelength $420 \mathrm{~nm}$ on a Bausch and Lomb Spectronic 20 Colorimeter.

Glucose Inhibition Determination

Approximately $10^{9}$ cells were inoculated into $50 \mathrm{ml}$-aliquots of Hershey.'s M-9 medium, containing 10\% Difco Bacto Proteose Peptone, but 
TABLE I

HERSHEY'S M-9 GROWTH MEDIUM

Material

Part A。

Distilled water

$\mathrm{Na}_{2} \mathrm{HPO}_{4} \cdot 12 \mathrm{H}_{2} \mathrm{O}$
(or)

$\mathrm{Na}_{2} \mathrm{HPO}_{4}$

$\mathrm{KH}_{2} \mathrm{PO}_{4}$

$\mathrm{inH}_{4} \mathrm{C} 1$

Part B.

$1 \mathrm{M} \mathrm{MgSO}_{4}$

$10^{-3} \mathrm{M} \mathrm{FeCl}_{3}$

$0.1 \mathrm{M} \mathrm{CaCl}_{2}$

$10 \%$ dextrose
Aniount

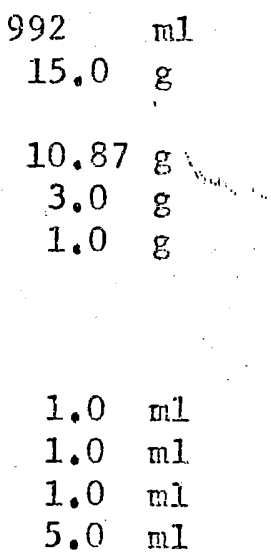


without dextrose. Protease activity was tested for in the above mecium plus in media containing cextrose in the concentrations of $5 \%, 0.5 \%$, $0.05 \%, 0.005 \%$. Tro controls were used: the first contained $10 \%$ proteose pentone, but no dextrose; the second contained no proteose. peptone, but had $5 \%$ dextrose. A third flask contained only Hershey's M-9 medium without either dextrose or proteose peptone. An earlier study in this laboratory indicated that proteose peptone was a good non-specific nediun for protease production by Pseudomonas aeruginosa, Ps $-1 C$,

Test cultures vere incubated for 14 - 16 hours on an incubator shaker water bath at $37^{\circ} \mathrm{C}$, and were then assayed for proteolytic activity.

Proteose Peptone Ana1ysis

Preparation of Proteose Peptone For Substrate Testing. Since proteose peptone provided a good substrate for the pseudomonal synthesis of the enzyme, it was thought that perhaps various components of proteose peptone could be separated and tested as inducers for protease formation. This might possibly give some general information as to the categories these nutritional requirements may belong.

Difco's Bacto Proteose Peptone, Iot number 492472 was used throughout this experiment. A $5 \%(\mathrm{w} / \mathrm{V})$ proteose peptone solution was dialyzed against large volumes of cold distilled water for two days, with changes of water twice a day. The dialysate remaining in the dialysis bag was Jyophilized.

A $10 \%$ solution of this lyophilized proteose peptone in distilled water was perculated through a descending sephadex G-10 gel column, with 
$0.05 \mathrm{M}$ tris buffer, pil 7.5 as the eluant. Three ml aliquots were collected with a Gilson GME Volumetric Linear Fractionator, Mode]. VL. Each fraction was read for optical density at wavelengths 260 and $280 \mathrm{~nm}$ with the Cilford 2000 spectrophotometer. Fractions vere pooled which represented the respective peaks, and labeled as pool I - pool V. Five $\mathrm{ml}$ samples from each of the respective pools vere added to $45 \mathrm{ml}$ aliquots of Hershey's $M-9$ medjum containing $0.05 \%$ dextrose. Each of these test flasks including a control flask with no sample were inoculated with Pseudononas aeruginosa Ps-1C from a starter culture, incubated for eighteen hours and assayed for protease production, Since the proteose peptone, (seph, G-10, I) from pool I indicated the best activity when tested as a substrate, this pool was lyophilized, and then a $10 \%$ solution was prepared. Five mis of this $10 \%$ solution was then perculated through a Sephadex G-75 gel column, and again three $\mathrm{m} 1$ fractions were collected and read at wavelengths 260 and $280 \mathrm{~nm}$ with the spectrophotometer. Three peaks were indicated and the respective fractions were pooled and labeled as: Proteose peptone, Seph G-10 I, Seph G-75 (I, II, or III).

The above three pools from the sephadex G-75 column were tested as substrate possibilities for Ps-1C protease elaboration as were the previous pools, except that a flask containing $1 \%$ Bacto, Vitamin-Free Casamino Acids was also used as well as a flask containing $1 \%$ proteose peptone in the crude, undialyzed form.

Casamino Acid Anolvsis Preparation of Casamino Acids for Substrate Testing. A $10 \%$ solution ( $(w / v)$ of Difco Bacto Vitarin-Free Casamino Acids in distilled 
water was dialyzed against distilled water in the cold for 24 hours. Both the solution renaining in the dialysis tube and the outside dialysis water were 1yophilized. One gram of each of these lyophilized portions was added to its respective flask containine $100 \mathrm{ml}$ of Hershey's $1-9$ medium with $0.01 \%$ dextrose. These, along with controls vere inoculated with Pseudomonas aeruginosa Ps-1C from a starter culture, incubated for 16 hours and assayed for proteolytic activity. Paper Electrophoresis of Casamino Acids. One gram of casamino acid dialyzed-out material was added to joo mi of 0.05 y tris buffer, pH 7.11 to serve as a stock sample to be tested on papar electrophoresis. A sheet of Whatman \# $3 \mathrm{M}$ paper was presoaked in 0.05 M phosphate buffer at the $\mathrm{pH}$ of the desired run to be'tested. The paper was placed on a plastic sheet laying on a metal plate cooled by circulating cold tap water. Each end of the paper rests in a buffer box where electrodes are connected to a Savant High Voltage Power supply, Mode1 HV $1000 \mathrm{CR}$. The left buffer box was connected to the cathode and the right buffer box to the anode.

Before the sample was put on, a potential vas applied to the system for a few minutes to equilibrate the buffer in the paper. With the syster turned off, a one $\mathrm{m} 1$ sample was applied to the center of the paper, and the potential was applied at a constant voltage for specified times.

At the end of the run, the paper was removed, air dried and cut lengthise, into two strips; one was about $1 / 3$ wide and the other about 
$2 / 3$ wide. The narrower strip was treated with $0.3 \%$ ninhydrin in $95 \%$ ethano1. (ETOn) to bring out the amino acid separation and make them visible,

Determination of The Effect of $10^{-4} \%$ Casamino Acid Dialysate For Substrate Testing. One $\mathrm{ml}$ of $1 \%$ casamino acid dialysate was added to $99 \mathrm{ml}$ of $\mathrm{M}-9$ mediun with $0.01 \%$ dextrose and inoculated with Pseudomonas aeruginosa Ps-IC starter cuJture. This was incubated on a shaker at $37^{\circ} \mathrm{C}$ for 18 hours and then assayed for proteolytic activity. A control flask which only contained the M-9 mediun with the dertrose was also incubated and assayed.

Gepn Electrophoresis of Casamino Acid Dialusate. A $500 \mathrm{ml}$ beaker was filled to the $300 \mathrm{ml}$ marker with dry powder Geon 428 Resin, lot number 5089. Alded to the Geon was $0.05 \mathrm{M}$ phosphate buffer of the pH of the electrophoresis run, uitil. the nixture was thick, wet, and consistent, but not runny. This was applied to a plastic trough $62 \mathrm{~cm} \times 6.5 \mathrm{~cm} \times$ $1.3 \mathrm{~cm}$ so that the Geon was consistently even. The trough was placed on the cooling plate mentioned in the paper electrophoresis section, and the Geon was connected to the buffer boxes by buffer soaked, Thatman \# 3 \% paper wicks. A center strip of Geon, $2-3 \mathrm{~cm}$ wide, was removed and replaced with Geon soaked in $10 \%$ Casamino acid dialysate. An electrical potential was applied for a specified time period to give a constant current of approximately 20 ma.

At the end of each run, $2-3 \mathrm{~cm}$ wide Geon segments were removed and put into individual beakers, numbered in order from the cathode, labeled as I, through the center of origin, towards the anode. The amino acids were eluted with $10 \mathrm{ml}$ of distilled water. A small sample 
from each fraction was spotted onto a strip of thatman $\mid$ k 3 paper, air dried, and treated with $0.3 \%$ ninhydrin fin ETOH to visually determine the migration of the amino acids and their separation in the buffer of the tested $\mathrm{pH}$.

The fractions were pooled into three fractions: Pool 1 is those fractions that migrated towards the cathode under the specified $\mathrm{pH}$ conditions; Pool II = those fractions which remained at the origin, i.e. did not migrate at that pil; and Pool III = those anino acids which migrated towards the anode under the specified pu conditions. These three pools were individually tested for containing nutritional requirements for protease production by Pseudomonas aeruginosa Ps-1C. A $150 \mathrm{mg}$ sample of lyophilized casamino acid Geon pool was added to $100 \mathrm{mls}$ of Hershey's $\mathrm{M}-9$ medium vith $0.05 \%$ dextrose in $250 \mathrm{ml}$ Erlenmeyer flasks stoppered with cotton plugs. These were inoculated from a starter culture, incubated 15 hours at $37^{\circ} \mathrm{C}$ on a shaker, and assayed for proteolytic activity.

A concentration of $40 \mathrm{ng} / \mathrm{ml}$ of lyophilized casamino acids, Geor electrophoresis, pool II was applied to a sephadex G-10 gel chromatography column. Two ml fractions were collected, and a sample from each was spotted on whatman 非 1 chromatography paper, air dried, and treated with ninhydrin. Five pools were obtained according to spot intensity and color. These pools were lyophilized and individually tested as substrate containing the required nutritional factors for protease production. Samples of $250 \mathrm{mg}$ each vere applied to $100 \mathrm{mI}$ aliquots of M-9 mediun, inoculated, incubated, and assayed as previously explained. 
Chromatography of Casamino Acj.ds. A number of chromatography systems were tried on the casamino acid dialysate, Geon electrophoresis (II), sephadex G-10 (J.I), to help illucidate which amino acids were involved as nutritional requirements for the production of protease by Pseudomonas aeruginosa Ps-1C. Table II lists the types of systems used with their respective solvents. The paper chromatography techniques were essentialiy those of Smith (1958). The thin layer techniques were those listed by pataks (1958). At the end of each run, the thin layer plate or paper was allowed to air dry before treatment with ninbydrin.

Thin layer plates of M-Celiulosepulver 300, Nacherey, Nagel and Co., $0.25 \mathrm{~mm}$ thick were prepared with a DESAGA Brinkmann layering device on glass plates.

In Figure 1, a schematic of the analysis of casamino acids as substrate for Ps-1C protease production is given.

Specific Amino Acid Analysis

Amino Acid Combinations Tested as Nutritional Requirements. All amino acids tested were of the L-form. Ammonia free glycine was obtained from Matheson Coleman and Be11, Co. The alanine, phenylalanine, leucine isoleucine, proline, hydroxyproline, and valine were obtained from Nutritional Biochemical Corporation. All other amino acids tested vere from Signa Chemical Company. The general procedure was to add $150 \mathrm{mg}$ of the appropriate anino acid to $100 \mathrm{ml}$ of Hershey's $M-9$ medium containing $0.05 \%$ dextrose, in $250 \mathrm{ml}$ Erlenmeyer flasks with cotton plug stoppers. The test flasks were incubated for 14 to 16 hours at $37^{\circ} \mathrm{C}$ on a shaker after being inoculated with one ml of starter culture. At 
TABLE II

CHROMATOGRAPHY SYSTEMTS USED

ON CASAMINO ACIDS

\begin{tabular}{|c|c|c|}
\hline $\begin{array}{l}\text { Types of } \\
\text { chromatography }\end{array}$ & $\begin{array}{l}\text { Solvent } \\
\text { systems }\end{array}$ & Sample \\
\hline $\begin{array}{l}\text { Thin layer, one } \\
\text { dimensional, } \\
\text { Cellulose MN } 300\end{array}$ & $\begin{array}{l}\mathrm{MeOH}-\mathrm{H}_{2} \mathrm{O}-\mathrm{Pyr} \quad(2.0: 5: 1) \\
\mathrm{Bu}-\mathrm{Ac}-\mathrm{H}_{2} \mathrm{O}(4: 1: 5) \\
\mathrm{Pyr}-\mathrm{H}_{2} \mathrm{O}(4: 1) \\
\mathrm{Bu}-\mathrm{Ac}_{2}-\mathrm{H}_{2} \mathrm{O}(12: 3: 5) \\
\mathrm{CHCl} \mathrm{H}_{3}-\mathrm{MeOH}-\mathrm{Am} \quad(2: 2: 1)\end{array}$ & $\begin{array}{l}\text { casamino acids, Geon } \\
\text { electectrophoresis II, } \\
\text { sephadex GIO, II. }\end{array}$ \\
\hline $\begin{array}{l}\text { Thin layer, two } \\
\text { dimensional, } \\
\text { Cellulose MT } 300\end{array}$ & $\begin{array}{l}\text { 1) } \mathrm{Bu}-\mathrm{Ac}-\mathrm{H}_{2} \mathrm{O}(4: 1: 5) \\
\text { 2) } \mathrm{Ph}-\mathrm{Am}(4: 1)\end{array}$ & $\begin{array}{l}\text { Casamino acids, Geon } \\
\text { electroticreeis II, } \\
\text { sephadex G10, I. . }\end{array}$ \\
\hline $\begin{array}{l}\text { Thin layer, two } \\
\text { dimensional, } \\
\text { Cellulose MN } 300\end{array}$ & $\begin{array}{l}\text { 1) } \mathrm{Bu}-\mathrm{Ac}-\mathrm{H}_{2} \mathrm{O}(12: 3: 5) \\
\text { 2) } \operatorname{Pyr}-\mathrm{H}_{2} \mathrm{O}(4: 1)\end{array}$ & $\begin{array}{l}\text { Casamino acids, Geon } \\
\text { electrophoresis II, } \\
\text { sephadex G10. II. }\end{array}$ \\
\hline $\begin{array}{l}\text { Thin layer, two } \\
\text { dimensional, } \\
\text { Cellulose MN } 300\end{array}$ & $\begin{array}{l}\text { 1) } \mathrm{MeOH}-\mathrm{CHCl}_{3}-\mathrm{Am}(2: 2: 1) \\
\text { 2) } \mathrm{MeOH}-\mathrm{H}_{2} \mathrm{O}-\mathrm{Pyr}(20: 5: 1)\end{array}$ & $\begin{array}{l}\text { Casamino acids, Geon } \\
\text { electrophoresis, II, } \\
\text { sephadex GIO, II. }\end{array}$ \\
\hline $\begin{array}{l}\text { Paper, one } \\
\text { dimensional } \\
\text { Whatman \#3M }\end{array}$ & $\mathrm{Bu}-\Lambda \mathrm{c}-\mathrm{H}_{2} \mathrm{O} \quad(4: 1: 5)$ & $\begin{array}{l}\text { Casamino acids, Geon } \\
\text { electrophoresis II, } \\
\text { sephadex GI0, (I,II, } \\
\text { III,IV, and V). }\end{array}$ \\
\hline
\end{tabular}

The listing of more than one solvent system in the one dimensional chromatography refers to the fact that each one was used separately with a different sample. The ratios of the solvents are all in terms of $(\mathrm{v} / \mathrm{v} / \mathrm{v})$. 
10\% Casamino acid dialysate

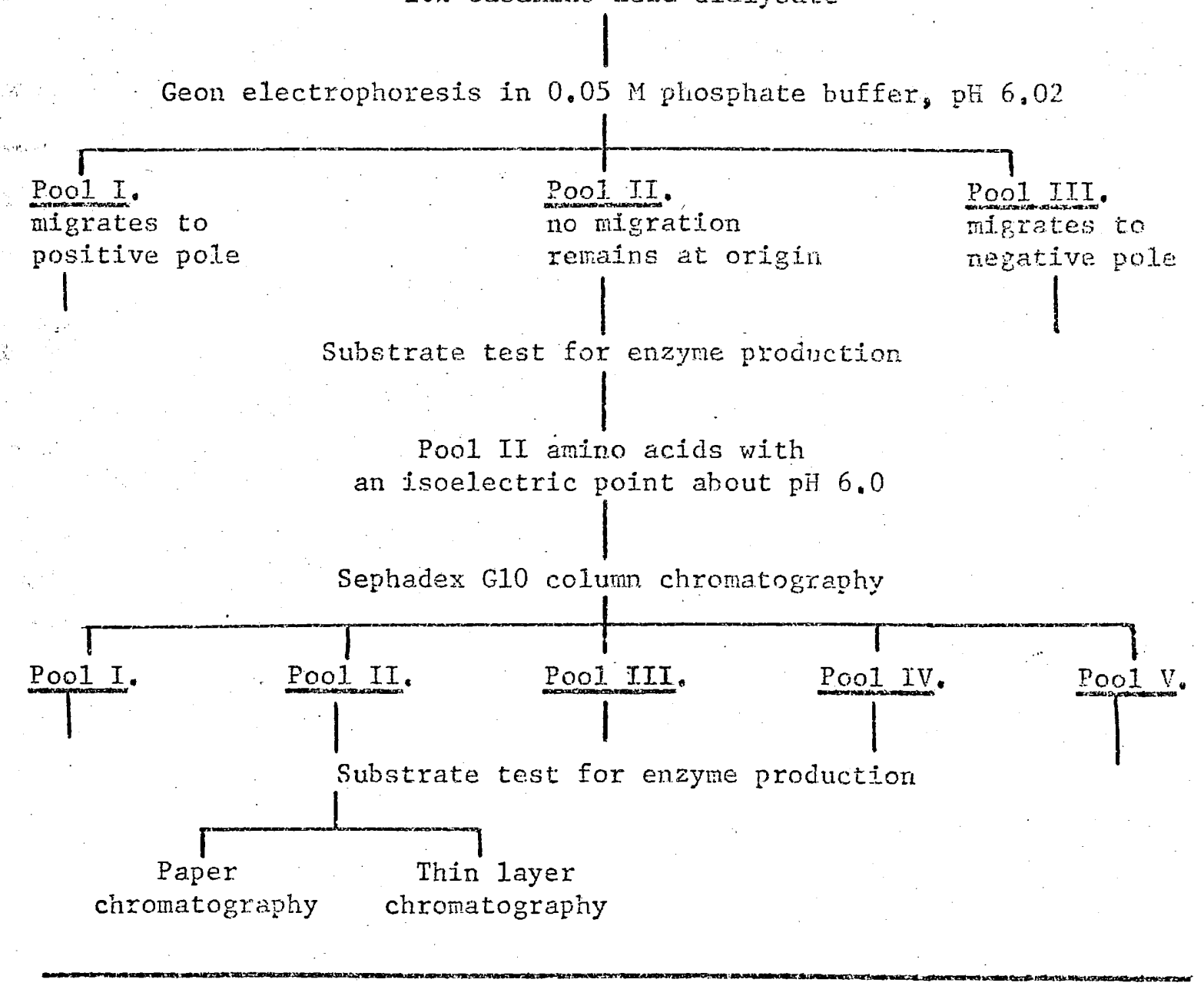

Figure 1. Schematic of the breakdown of casamino acids for determination of amino acid requirements for Ps-1C protease production. 
the end of the incubation time the culcures vere assayed for proteolytic activity。

In a few cases, $15 \mathrm{mg}$ amounts of amino acids were added to $10 \mathrm{~m} 1 \mathrm{~s}$ of $\mathrm{M}-9$ medium in $30 \mathrm{ml}$ test tubes. These vere inoculated with $1 / 10 \mathrm{ml}$ starter culture, incubated, and assayed as vere the flasks. Amino Acid Concentraion Requirement. In all cases, l-amino acjis were added in varying concentrations to $10 \mathrm{~m} . \mathrm{l}$ of Hershey's $1-9$ medium containing $0.05 \%$ dextrose. One tenth ml of starter culture vas added to the experimental test tubes ( $30 \mathrm{ml}$ size) which were incubated at $37^{\circ} \mathrm{C}$ or a water bath shaker for 14 to 16 hours. At that tine they were then assayed for proteolytic activity.

All amino acid concentration experiments were performer in duplicate or triplicate, and the optical densities vere averaged from the proteolytic assays.

Determination of Dextrose Concentration and Repression

The culture redia contaired $10 \mathrm{ml}$ of Hershey's $M-9$ mediun without dextrose, except that which was added at concentrations to be tested. The medium was supplemented with valine, $2.0 \mathrm{ng} / \mathrm{ml}$; isoleucine, $1.0 \mathrm{mg} /$ $\mathrm{ml}$; and phenylalanine, $0.5 \mathrm{mc} / \mathrm{mI}$. The dextrose used was Mallinckrodt dextrose Anhydrous; Mallinckrodt Chemical Works in concentrations of $1.0 \%$ to $0.001 \%$. Tro controls were employed; one had the amino acids, but no dextrose; and the other had neither dextrose nor amino acids. The test tubes were incubated for 20 hours on an incubator shaker water bath at $37^{\circ} \mathrm{C}$ and then assayed for proteolytic activity. 
Growth Curves

Grovth Curve Vs. Optical Density at $660 \mathrm{~mm}$. A $50 \mathrm{ml}$ aliquot of NBYE is inoculated with Pseudomonas aeruginosa Ps-1C and incubated 18 hours at $37^{\circ} \mathrm{C}$ on a Metabolyte Waterbath Shaker, New Brunswick Scientifjc Company, Incs at 300 RPM. At zero time one ml of starter culture is inoculated into the test flask.

The culture medium consists of $99 \mathrm{ml}$ of sterile NBYE in a $250 \mathrm{ml}$ Erlenmeyer flask with a cotton plug stopper. This is incubated at $37^{\circ} \mathrm{C}$ on a Gyrotory Shaker, New Brunswick Scientific Company, Inco, pPP setting of 6.5 .

All nedia including the $9 \mathrm{ml}$ and the $99 \mathrm{ml}$ dilution blanks were pre-sterilized by autoclaving for 15 minutes at $250^{\circ} \mathrm{C}$.

The agar plates were made with approxinately $2.5 \mathrm{mi}$ of NBYF agar, which consisted of the same concentrations of nutrient broth and yeast extract as previously mentioned plus $1.5 \%$ Difeo Bacto-Agar, Difeo Laboratories. All agar plates were incubated for one day at room temperature and one day at $37^{\circ} \mathrm{C}$ before using in order to eliminate contaminated plates.

Five to eight ml samples were withdrawn from the test culture media at specified times and the optical density was read at wavelength $660 \mathrm{~nm}$ with a Bausch and Lomb Spectronic 20 colorimeter, using the red filter. The time intervals at which the culture density was read optically and the agar plates were inoculated are as follows: $0,1,2$, $3,4,5,6,7,8,9,10,12,14,16,18,20$, and 24 hours. The agar plates were inoculated by making the specified dilutions (Table III) and withdrawing $0.1 \mathrm{ml}$ from a $10 \mathrm{ml}$ dilution tube with a 
TARLE III.

GRONTH CURVE OF PSEUDOMONAS AERUCINOSA

VERSES OPTICAL DENSITY AT

WAVELENGTH $660 \mathrm{NM}$

\begin{tabular}{|c|c|c|c|c|c|}
\hline $\begin{array}{l}\text { Incubation } \\
\text { time in } \\
\text { hours }\end{array}$ & & $\begin{array}{l}\text { Di.lu } \\
\text { Plate }\end{array}$ & $\begin{array}{l}\text { ons pe } \\
\text { ony co }\end{array}$ & & $\begin{array}{l}\text { Optical density } \\
\text { at wavelength } \\
660 \mathrm{~nm}\end{array}$ \\
\hline 0 & $\begin{array}{l}10^{-1} \\
C\end{array}$ & $\begin{array}{l}10^{-2} \\
C\end{array}$ & $\begin{array}{l}10^{-3} \\
c\end{array}$ & $\begin{array}{l}10^{-4} \\
\mathrm{C}\end{array}$ & 0.010 \\
\hline 1 & $\begin{array}{l}10^{-1} \\
\mathrm{C}\end{array}$ & $\begin{array}{l}10^{-2} \\
\mathrm{C}\end{array}$ & $\begin{array}{l}10^{-3} \\
c\end{array}$ & $\begin{array}{l}10^{-4} \\
609\end{array}$ & 0.010 \\
\hline 2 & $\begin{array}{l}10^{-2} \\
\mathrm{C}\end{array}$ & $\begin{array}{l}10^{-3} \\
c\end{array}$ & $\begin{array}{l}10^{-4} \\
C\end{array}$ & $\begin{array}{l}10^{-5} \\
194\end{array}$ & 0.022 \\
\hline 3 & $\begin{array}{l}10^{-2} \\
C\end{array}$ & $\begin{array}{l}10^{-3} \\
C\end{array}$ & $\begin{array}{l}10^{-4}-4 \\
C\end{array}$ & $\begin{array}{l}10^{-5} \\
c\end{array}$ & 0.060 \\
\hline 4 & $\begin{array}{l}10^{-3} \\
C\end{array}$ & $\begin{array}{l}10^{-4} \\
C\end{array}$ & $\begin{array}{l}10^{-5} \\
\mathrm{C}\end{array}$ & $\begin{array}{l}10^{-6} \\
1.66\end{array}$ & 0.090 \\
\hline 5 & $\begin{array}{l}10^{-3} \\
\mathrm{C}\end{array}$ & $\begin{array}{l}10^{-4} \\
C\end{array}$ & $\begin{array}{l}10^{-5} \\
C\end{array}$ & $\begin{array}{l}10^{-6} \\
350\end{array}$ & 0.118 \\
\hline 6 & $\begin{array}{l}10^{-3} \\
c\end{array}$ & $\begin{array}{l}10^{-4} \\
c\end{array}$ & $\begin{array}{l}10^{-5} \\
\mathrm{C}\end{array}$ & $\begin{array}{l}10^{-6} \\
415\end{array}$ & 0.140 \\
\hline 7 & $\begin{array}{l}10^{-4} \\
c\end{array}$ & $\begin{array}{l}10^{-5} \\
C\end{array}$ & $\begin{array}{l}10^{-6} \\
435\end{array}$ & $\begin{array}{l}10^{-7} \\
68\end{array}$ & 0.155 \\
\hline 8 & $\begin{array}{l}10^{-4} \\
C\end{array}$ & $\begin{array}{l}10^{-5} \\
\mathrm{C}\end{array}$ & $\begin{array}{l}10^{-6} 6 \\
552\end{array}$ & $\begin{array}{l}10^{-7} \\
55\end{array}$ & 0.172 \\
\hline 9 & $\begin{array}{l}10^{-5} \\
\mathrm{C}\end{array}$ & $\begin{array}{l}10^{-6} \\
\mathrm{C}\end{array}$ & $\begin{array}{l}10^{-7} \\
65\end{array}$ & $\begin{array}{l}10^{-8} \\
6\end{array}$ & 0.181 \\
\hline 10 & $\begin{array}{l}10^{-5} \\
\mathrm{C}\end{array}$ & $\begin{array}{l}10^{-6} \\
\mathrm{C}\end{array}$ & $\begin{array}{l}10^{-7} \\
91\end{array}$ & $\begin{array}{l}10^{-8} \\
9\end{array}$ & 0.198 \\
\hline 12 & $\begin{array}{l}10^{-5} \\
\mathrm{C}\end{array}$ & $\begin{array}{l}10^{-6} \\
\mathrm{C}\end{array}$ & $\begin{array}{l}10^{-7} \\
93\end{array}$ & $\begin{array}{l}10^{-8} \\
9\end{array}$ & 0.220 \\
\hline
\end{tabular}


TAELE III

Continued

\begin{tabular}{|c|c|c|c|c|c|}
\hline \multirow{2}{*}{$\begin{array}{l}\text { Incubation } \\
\text { time in } \\
\text { hours } \\
14\end{array}$} & \multicolumn{4}{|c|}{$\frac{\text { Dilutions per }}{\text { plate colony count }}$} & \multirow{2}{*}{$\begin{array}{l}\text { Optical density } \\
\text { at wavelength } \\
660 \mathrm{~nm} \\
0.242\end{array}$} \\
\hline & $\begin{array}{l}10^{-5} \\
\mathrm{C}\end{array}$ & $\begin{array}{l}10^{-6} \\
c\end{array}$ & $\begin{array}{l}10^{-7} \\
97\end{array}$ & $\begin{array}{l}10^{-8} \\
15\end{array}$ & \\
\hline 16 & $\begin{array}{l}10^{-5} \\
\mathrm{C}\end{array}$ & $\begin{array}{l}10^{-6} \\
\mathrm{C}\end{array}$ & $\begin{array}{l}10^{-7} \\
1.36\end{array}$ & $\begin{array}{l}10^{-8} \\
40\end{array}$ & 0.262 \\
\hline 18 & $\begin{array}{l}10^{-5} \\
c\end{array}$ & $\begin{array}{l}10^{-6} \\
\mathrm{C}\end{array}$ & $\begin{array}{l}10^{-7} \\
128\end{array}$ & $\begin{array}{l}10^{-3} \\
1.5\end{array}$ & 0.273 \\
\hline 20 & $\begin{array}{l}10^{-5} \\
\mathrm{C}\end{array}$ & $\begin{array}{l}10^{-6} \\
c\end{array}$ & $\begin{array}{l}10^{-7} \\
142\end{array}$ & $\begin{array}{l}10^{-8} \\
9\end{array}$ & 0.290 \\
\hline 24 & $\begin{array}{l}10^{-5} \\
c\end{array}$ & $\begin{array}{l}10^{-6} \\
\mathrm{C}\end{array}$ & $\begin{array}{l}10^{-7} \\
98\end{array}$ & $\begin{array}{l}10^{-8} \\
9\end{array}$ & 0.288 \\
\hline
\end{tabular}

The symbol $C$ indicates confluent growth. 
pipetre and applying this to the agar surface and spreading with an alcohol. flamed glass spreading rod. The inoculated agax plates are incubated for $10-18$ hours at $37^{\circ} \mathrm{C}$ in a Napco Incubator, Model 320 . The colonies were counted and recorded on a Sansaur Bacti-Counter, Aloe Scientific Co. and a Klett Pressure Counter, Klett Mfg. Co.

Essentially the method of Eagon (1968) has been employed for the methods of the growth curve.

The number of cells per mit at a specified time are calculated by: $\frac{10^{2} \times \operatorname{man} 2 \mathrm{dilution} \times \text { number of colonies/plate }}{\left.10^{2} \mathrm{~m}\right] \mathrm{s} \text { of culture }}=\mathrm{n}$ Where $\mathrm{n}=$ number of cells per ml. (Eq. 1)

Log of the cell number is determined (Corliss and Berglund, 1958) and plotted against optical density at $660 \mathrm{~nm}$.

Growth and Protease Production Versus Time. A stattex culture wes prepared as previously stated, and $1.0 \mathrm{ml}$ was applied ar zero titne to $500 \mathrm{ml}$ of test culture in a 2 licex Erlenmeyer flask with a cotton plug stopper.

The test culture mediun contained Hershey's $M-9$ medium with $0.05 \%$ dextrose and supplemented with $0.5 \mathrm{mg} / \mathrm{ml}$ phenylalanine, $0.75 \mathrm{mg} / \mathrm{ml}$ isoleucine, and $2.0 \mathrm{mg} / \mathrm{ml}$ valine.

The inoculated test culture was incubated on a shaker at $37^{\circ} \mathrm{C}$. At specified time intervals, three samples were removed. A sample of $3 \mathrm{ml}$ was removed to determine the culture's optical denstey at $660 \mathrm{~mm}$ and this was returned to the culture flask. When the readings were 'greater than 0.500 , a $1 / 10$ dilution in sterile Hershey's $N \times 9$ nedlum was made, and the $0 . D$, was recorded after the value was multiplied by ten. 
A second sample of $0.1 \mathrm{ml}$ of culture was removed for proteolytic assay by previously described method.

A thitd sample of $1.0 \mathrm{ml}$ of culture was removed for raking appropriate dilutions in sterile NBYE for plating and determination of cell number/m1 of culture as done in the growth curve above.

The $10 \mathrm{~g}$ of the cell number, culture optical density at $660 \mathrm{~mm}$, and proceolytic assay optical density at $420 \mathrm{~nm}$ were plotted against time.

Divalent Metal Ion Concentretson Reyuirentens. All divalent metal ions tested were analytical reagent grade chemicals fron hollinckrodt

Chemical Works. The $\mathrm{Mg}^{+4}$ solucion was prepared from $\mathrm{MgSO}_{4} \cdot 7 \mathrm{H}_{2} \mathrm{O} ; \mathrm{Zn}^{++}$ from $\mathrm{ZnSO}_{4} \cdot 7 \mathrm{H}_{2} \mathrm{O}$; Cot fxom $\mathrm{CoCl}_{2} \cdot 6 \mathrm{H}_{2} \mathrm{O}$; $\mathrm{Cu}^{++}$fxon $\mathrm{CuSO}_{4} \cdot 5 \mathrm{H}_{2} \mathrm{O}$; and the $\mathrm{Ca}^{++}$from $\mathrm{CaCI}_{2} \cdot 2 \mathrm{H}_{2} \mathrm{O}$.

For the $\mathrm{Mg}^{++}$and $\mathrm{Zn}^{++}$concentration experiments, the culture medium contained 100 ml of Hershey's $M-9$ part A only, with $0.05 \%$ dextrose and supplemented with $2.0 \mathrm{mg} / \mathrm{ml}$ valine, $1.0 \mathrm{mg} / \mathrm{mi}$ isoleucine, and $0.5 \mathrm{mg} / \mathrm{ml}$ phenylanaline. The tests for the other divalent ions employed $50 \mathrm{ml}$ of the sane nedium. In all cases the mediun was sterilized in 250 ml Erlenneyer flasks. Varying concentrations of the ion to be tested were added to the experinental flasks before sterilin. zation. A11 experiments were duplicated and averaged in the results. Following inoculation from a startex culture the flasks were incubated on a shaker at $37^{\circ} \mathrm{C}$ for $14-16$ hours, and then assayed for proteolytic activity. 
RESULTS

Glucose Inhibition Determination

In both cases, the first using $10 \%$ proteose peptone in Hershey's M-9 medium and the second where Hershey's M-9 medium was supplemented with $0.05 \mathrm{ng} / \mathrm{ml}$ phenylalanine, $1.0 \mathrm{mg} / \mathrm{ml}$ isoleucine, and $2.0 \mathrm{mg} / \mathrm{ml}$ valine, there was an apparent inhibition of enzyme production at glucose concentrations greater than $0.05 \%$. In Figure 2 both experinental. conditions indicate that the best enzyme production occurred when the glucose concentration. was maintained at $0.05 \%$. It was noted visually, though not tested specifically that there was good growth at all concentrations.

Proteose Peptone Analysis

A $10 \%$ proteose peptone solution, perculated through a descending sephadex G-10 column gave rise to five peaks as indicated by the optical density of the fractions read at wavelengths 260 and $280 \mathrm{~nm}$. As indicated in Figure $3 a$, the largest anount of material came off in Pool I.

These five poois were tested for ability to stimulate protease production, and it was found that only pool. I gave rise to any appreciable proteolytic activity under the the appropriate conditions.

Ten $\mathrm{ml}$ of pool I. was applied to a sephadex G-75 descending column and three sub-pools were obtained by this procedure, see Figure $3 b$. Five mil samples from each of these pools were tested as inducers for protease formation, as were also $5 \mathrm{mls}$ of $10 \%$ casamino acids, and $5 \mathrm{mls}$ of $3.0 \%$ crucle proteose peptone. None of the pools from the sephadex G-75 


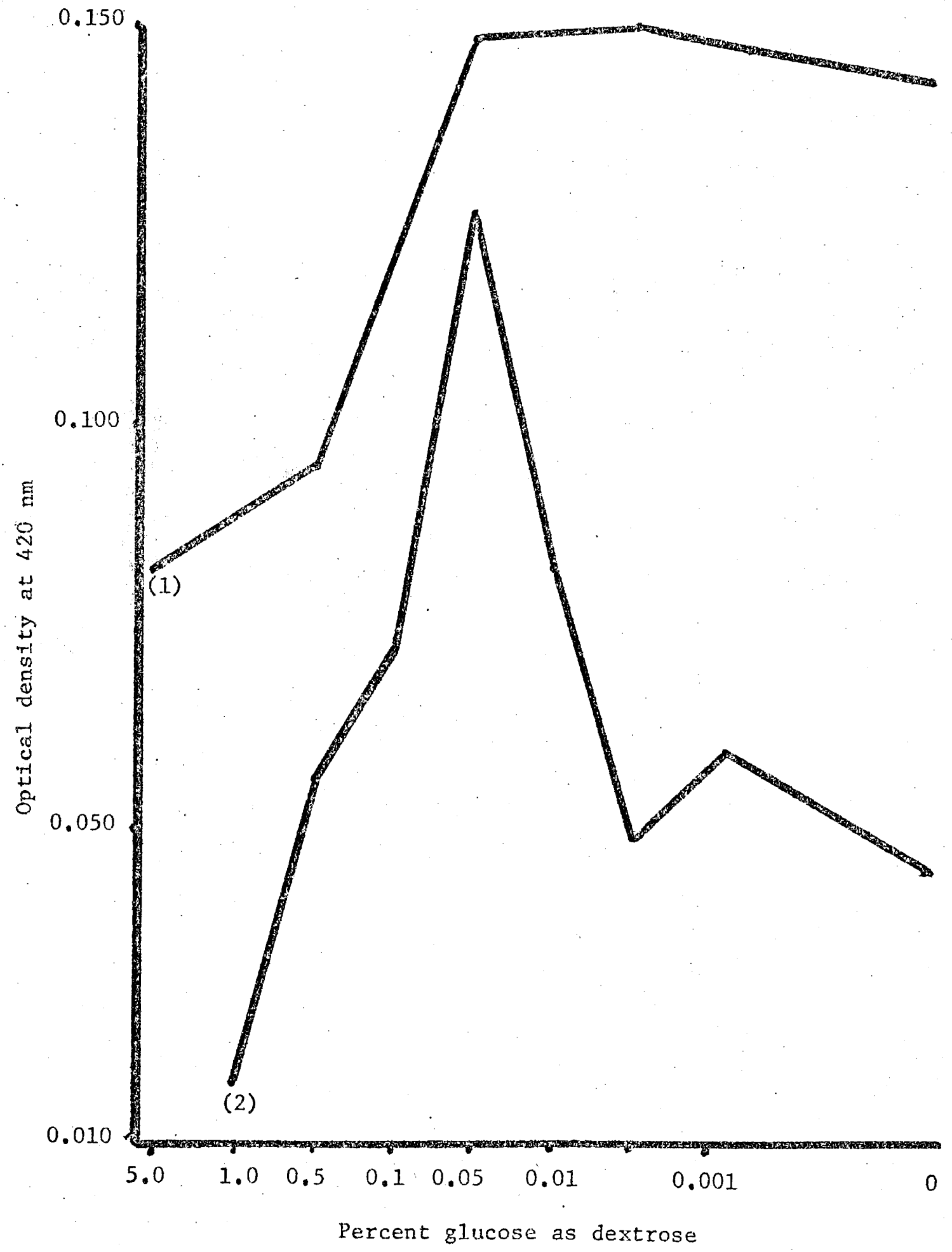

Figure 2. Dextrose concentration determination for the best Ps-1C protease production. The results are the average of two experiments. (1) $M-9$ medium plus proteose peptone, and (2) $M-9$ medium supplemented with valine, isoleucine, and phenylalanine. 


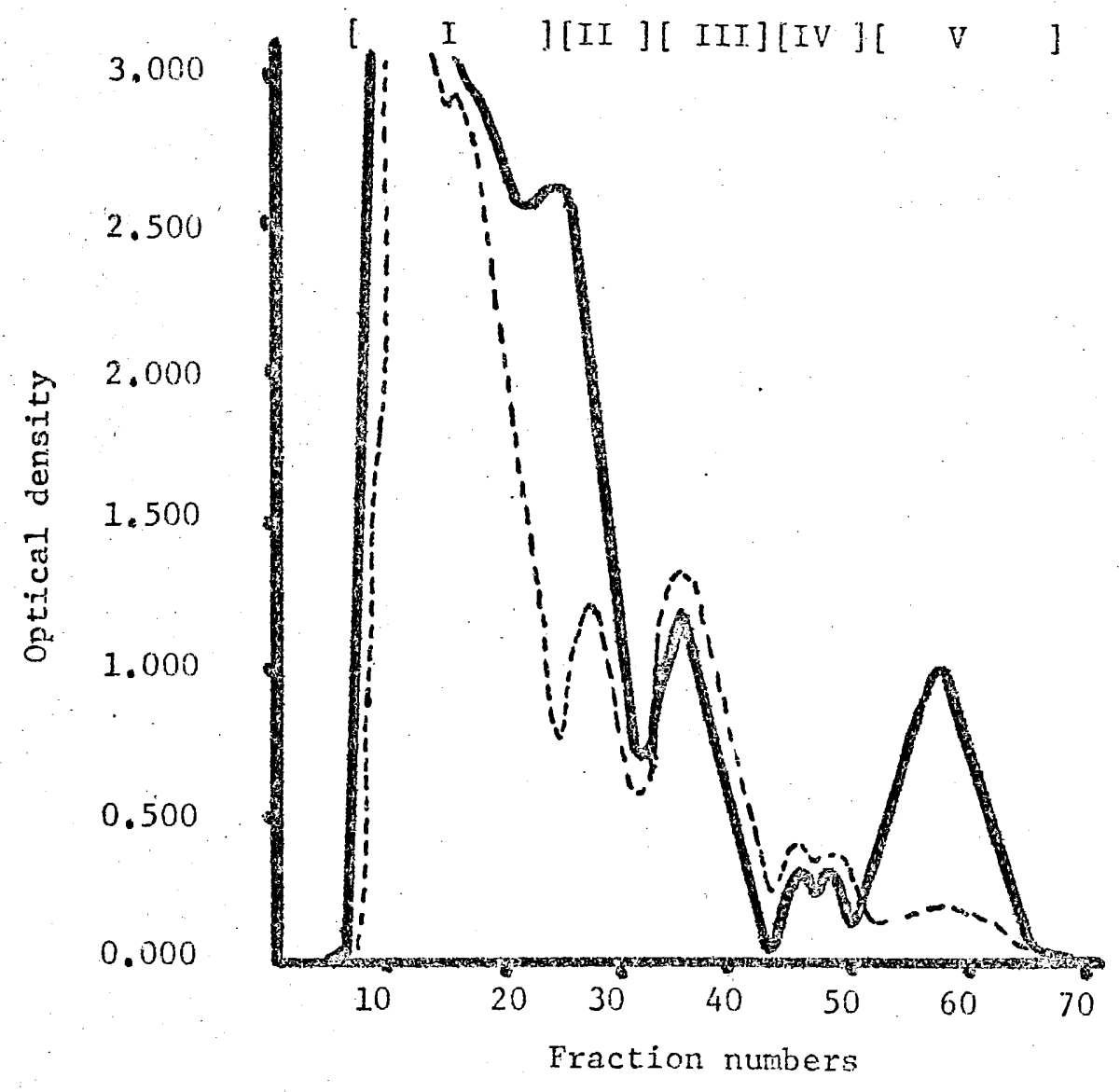

Figure 3a. Sephadex G10 column chromatography of $10 \%$ proteose peptone. Solid line indicates readings at wavelength $260 \mathrm{~nm}$, and dotted line at $280 \mathrm{~nm}$. 


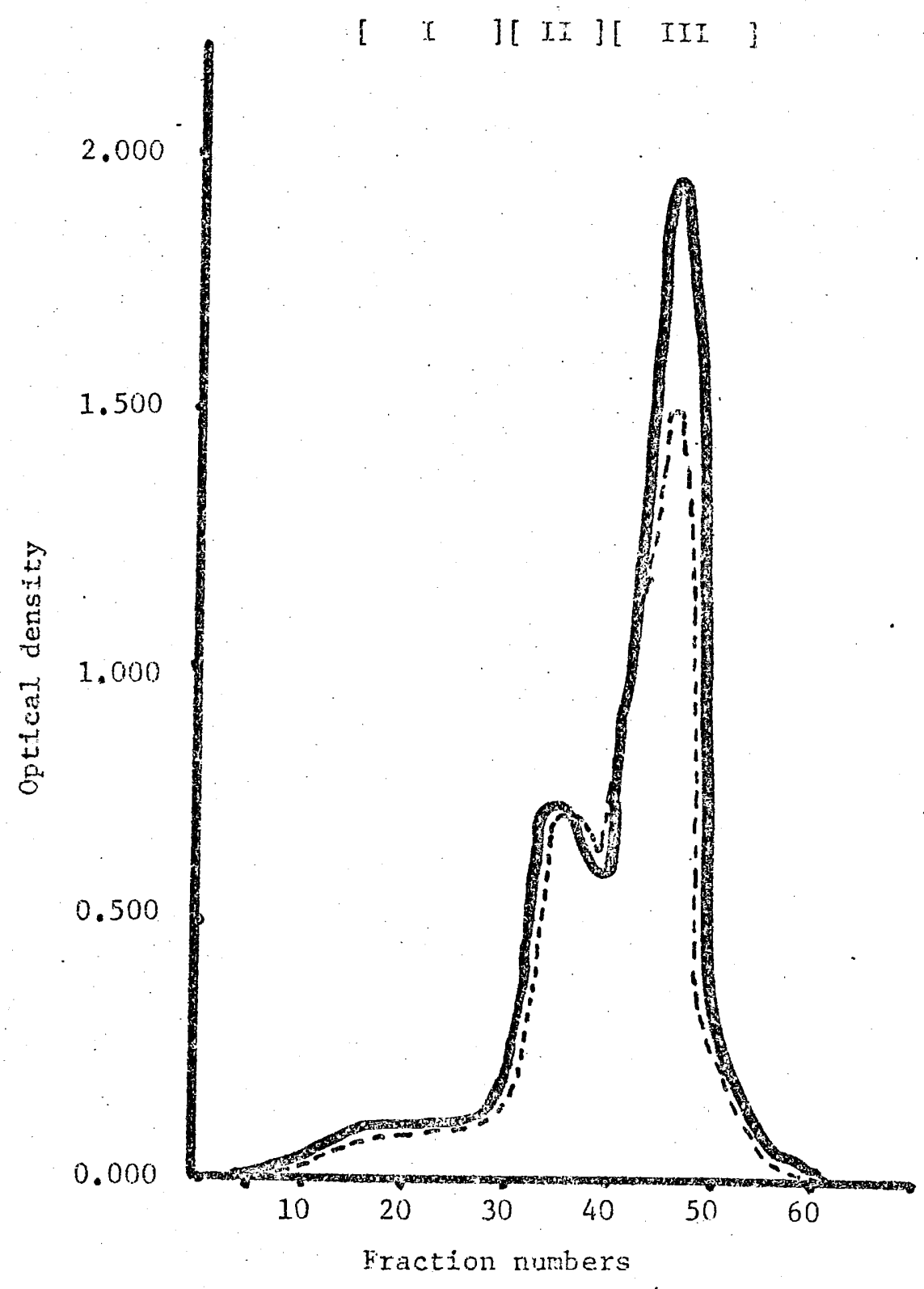

Figure 3b. Sephadex 675 column chronatography of proteose peptone sephadex Glo, pool I. Solid line indicates readings at wavelength $260 \mathrm{~nm}$, and dotted line at $280 \mathrm{~nm}$. 
treatment gave rise to appreciable protease production, as indicated by enzyne activity, however the casamino acid samrle and proteose peptone contro1 were active.

The proteose peptone sephadex $G-10$ pools and the sephadex $G-75$

pools were lyophilized and retested as 10\% solutinns in Hershey's $\{-9$ media. Although there appeared to be good growth, there was not appreciable protease production in any of the pools.

The sephadex treatnents were tried in reverse. Ten percent proteose peptone mas first put through a descending sephadex G-75 colum. This resulted into two peaks of material, see Fieure $3 \mathrm{c}$, and $100 \mathrm{ng}$ of each lyophilized pool was put in $50 \mathrm{ml}$ of $M-9$ mediun and tested as inducer for ps-1C protease production, Pool IT, did give appreciable enzyme production.

A $10 \%$ solution of 1yophilized proteose peptone, sephadex G-75, pool I.I. was chromatographed on a sephadex G-10 column. Three peaks of naterial (see Figure 3d) were separated, lyophilized and tested as inducer for protease production. None of these three pools gave rise to any proteolytic activity.

Casamino Acid Analysis. Since it had earlier been determined that casamino acios right serve as inducer for protease elaboration by Pseudomonas aeruginosa Ps-1C, a 10\% solution was prepared and dialyzed against distilled vater. The naterial remaining in the dialysis tubing and that which passed into the distilled water vere lyophilized and used as inducers for enzyne production. Table IV indicates that the material which dialyzed into the distilled water provided the required nutrients for the bacteriun to elaborate the enzyne. Paper electrophorests of casamino acid dialysates were performed: 


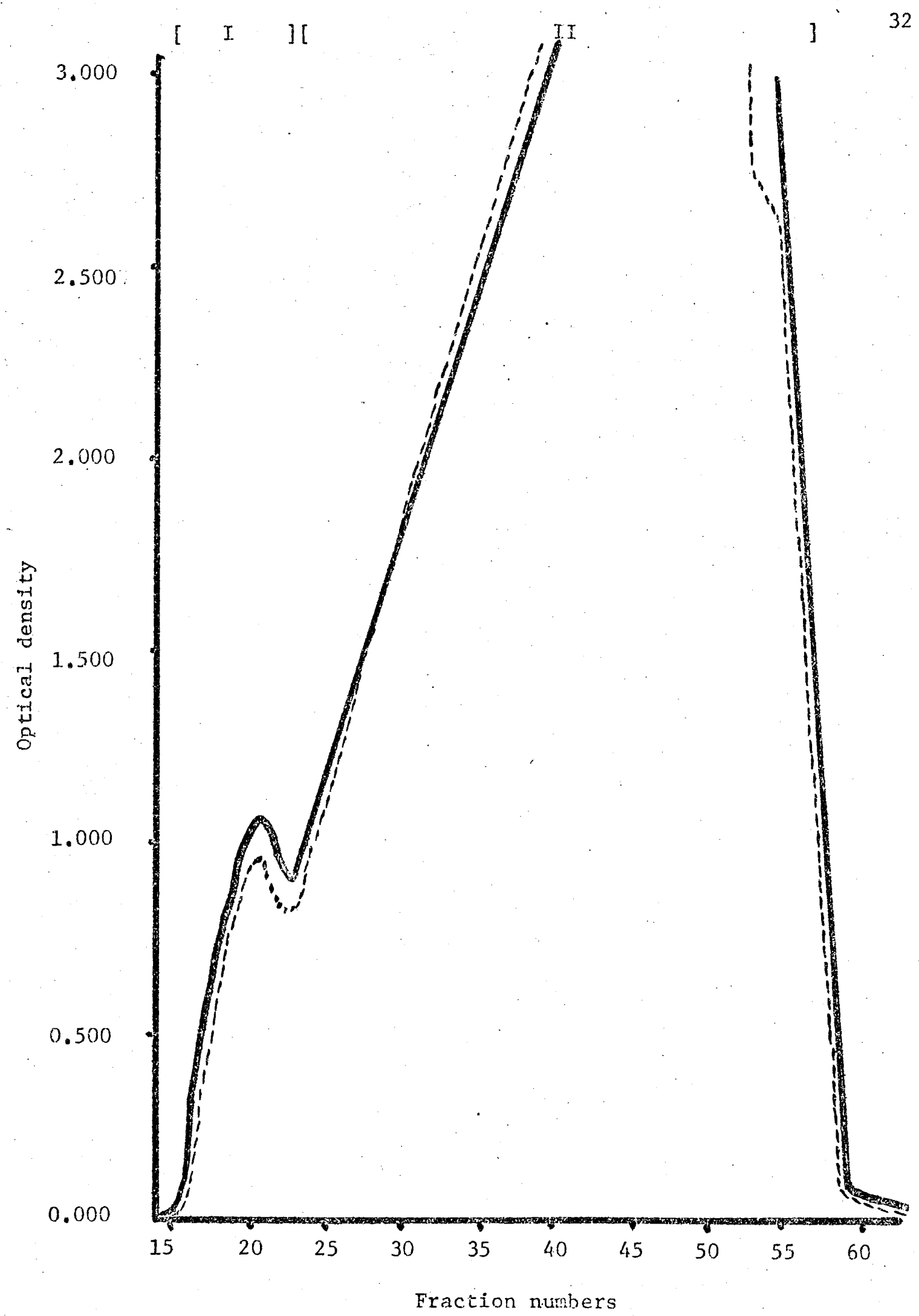

Figure 3c. Sephadex G75 colum chromatography of $10 \%$ proteose peptone. Solid line indicates readings at wavelength $260 \mathrm{~nm}$, and dotted line at $280 \mathrm{~nm}$. 


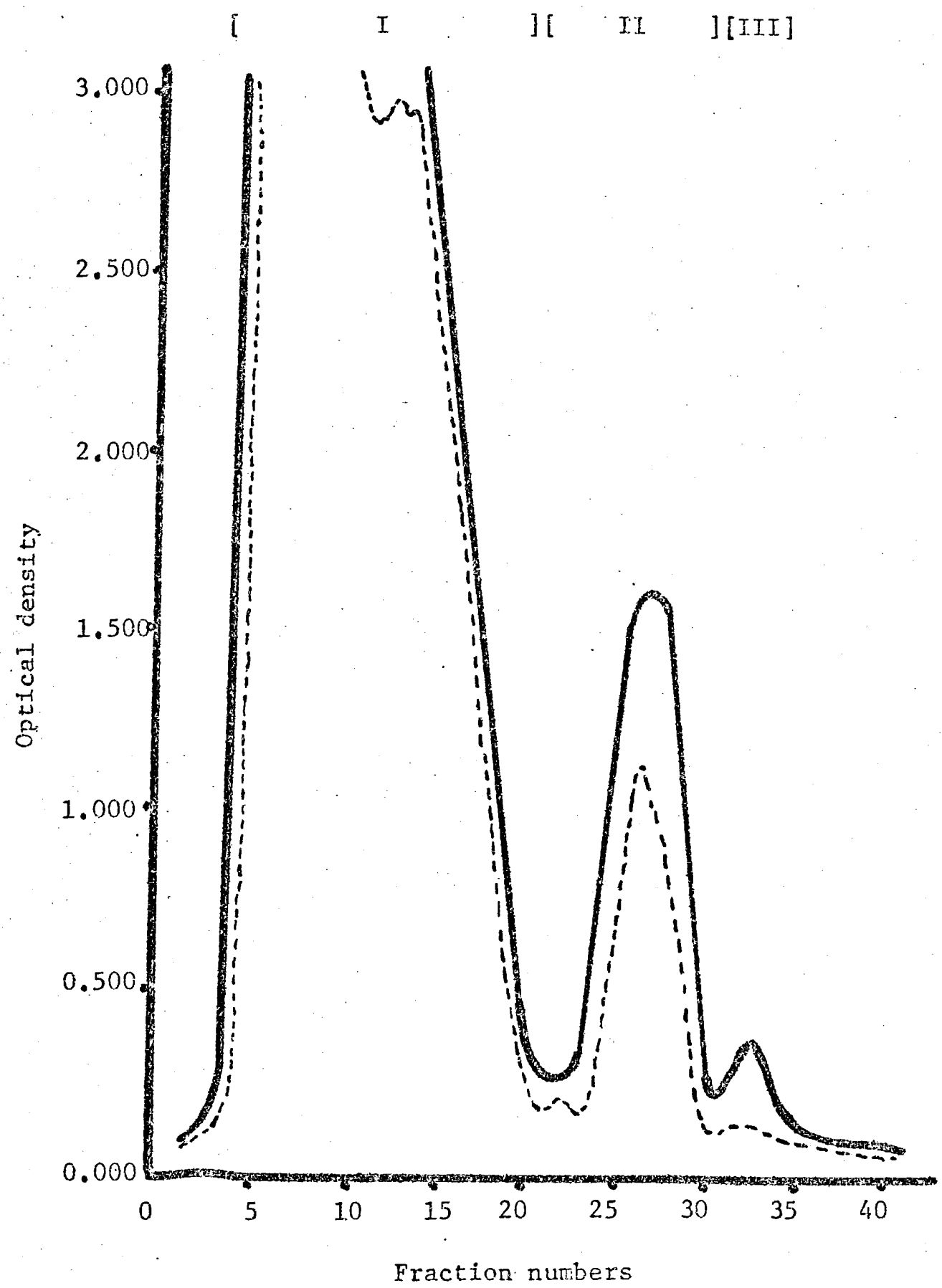

Figure 3d. Sephadex G10 column chromatography of $10 \%$ proteose peptone, sephadex 675 , pool II. Solid line indicates readings of optical density at wavelength 260 n.m, and dotted line at $280 \mathrm{~nm}$. 
TABLE IV

CASAMTNO ACII DIALYSATE

SUBSTRATE EYPERIMENT

\begin{tabular}{|c|c|c|c|c|c|}
\hline \multirow[b]{2}{*}{ Flask } & \multirow{2}{*}{$\begin{array}{l}\text { Amount of } \\
\text { Hexshey's } 1-9\end{array}$} & \multirow{2}{*}{ Amount } & \multicolumn{2}{|c|}{ Casanino acids } & \multirow{2}{*}{$\begin{array}{l}\text { optical } \\
\text { density }\end{array}$} \\
\hline & & & Amolint & Preparatiot & \\
\hline$\therefore \mathrm{A}$ & $100 \mathrm{ml}$ & $0.01 \%$ & 1.044 & $\begin{array}{l}\text { Iaterial in the } \\
\text { dialysis tube }\end{array}$ & 0.060 \\
\hline B & $100 \mathrm{ml}$ & $0.01 \%$ & 1.000 & $\begin{array}{l}\text { Material in the } \\
\text { dialysis water }\end{array}$ & 0.115 \\
\hline C & $100 \mathrm{mI}$ & $0.01 \%$ & 1.000 & $\begin{array}{l}\text { Non-dialyzed, } \\
\text { crude }\end{array}$ & 0.025 \\
\hline D & $100 \mathrm{~m} 1$ & $0.01 \%$ & none & -.-n-m.n- & 0.005 \\
\hline
\end{tabular}

The optical density readings are at wavelength $420 \mathrm{~nm}$, and the amount of casamino acids is in grans. 
using $0.05 \mathrm{M}$ tris buffer pH 7.11 , and $0.05 \mathrm{M}$ phosphate buffer with pH's of 6.0 to 8.0 . The times of the runs were from 20 minutes to 180 minutes with voltages of $600 \mathrm{~V}$ and currents of about $30 \mathrm{ma}$. The acid pH's gave better separation than did the basic or neutral pil's. However substrate tests indicated that not enough material could be obtained by this method of separation in order to obtain meaningful data.

Geon electrophoresis of $10 \%$ casamino acid dialysate permitted larger quantities of separated material to be obtained. After the technique tas developed, the average geon electrophoresis run vas about 5 hours with $800 \mathrm{~V}$ and current from 15 to $20 \mathrm{ma}$. Figure 4. shows an average geon electrophoresis experiment and the respective sample spot paper to detemine the separation of the anino acids. When the Iyophilized pools from the geon electrophoresis of casamino acids were tested as substrate for Fs-1C protease production, it was determined that pool II, or the material remaining at the origin best contributed to protease synthesis. This was true when pool II, was tested singularly or in combination with the other pools, as indicated in Table $V$. This experiment was repeated several times and the same results occurred.

To further separate the casanino acids, pool II from the coon electrophoresis treatment was lyophilized and a sample was resuspended in the eluting buffer and applied to a sephadex G-10 column. A spot-ogram was made to determine which 2 .n 1 fractions contained the separated amino acids. An average spot-o-gran is shown in Figure 5. where the five pools were established. The pools, I through $V$ vere lyophilized and tested for substrate which contributes to protease production for 


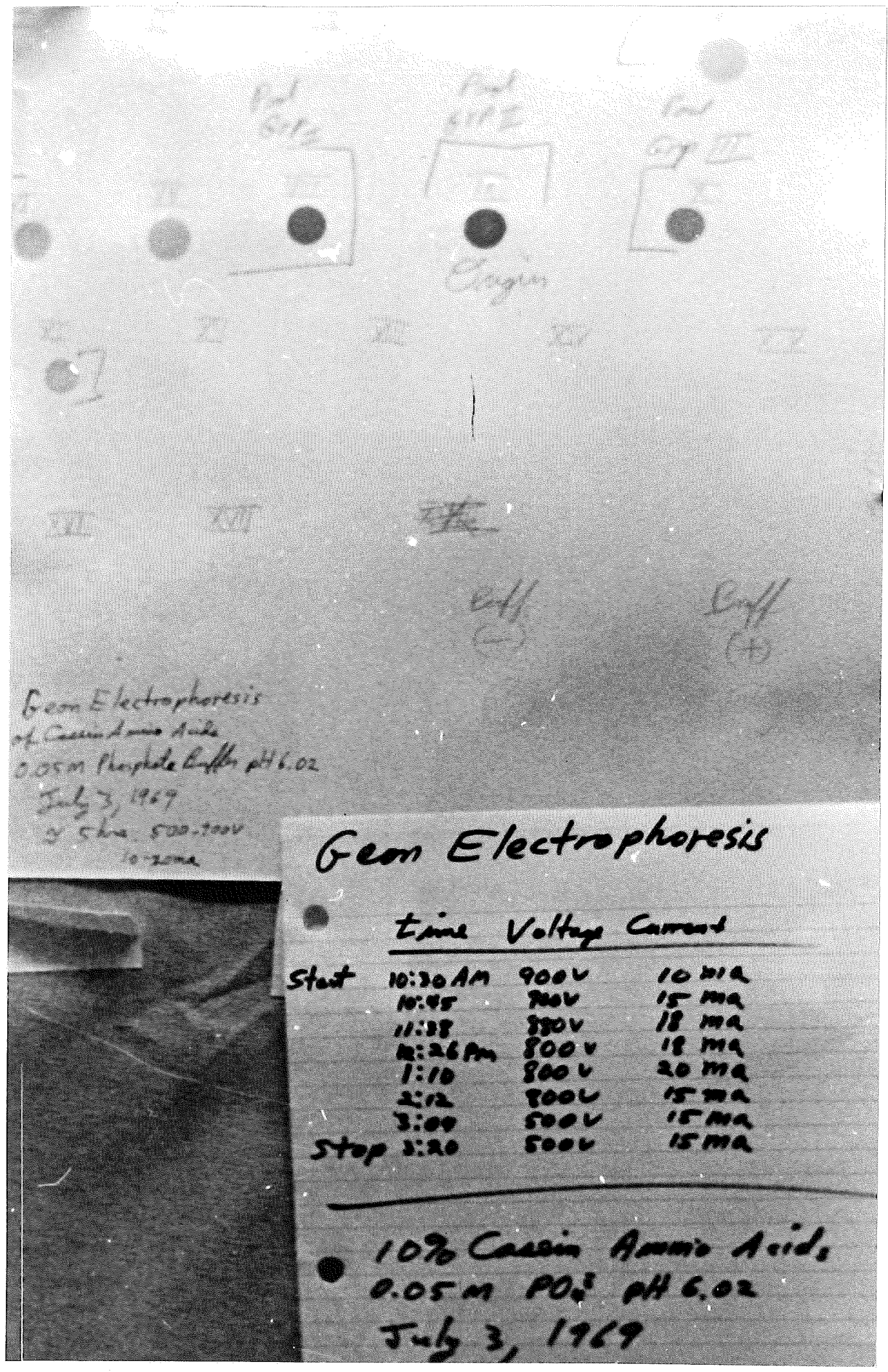

Figure 4. Geon electrophoresis of casamino acids using a $0.05 \mathrm{M}$ phosphate buffer, pH 6.02 . 


\section{TABLE $\quad \square$}

SUSSTRATE TESTS OF CASAMTNO ACIDS

GEON EIECTROPHORESIS POOLS

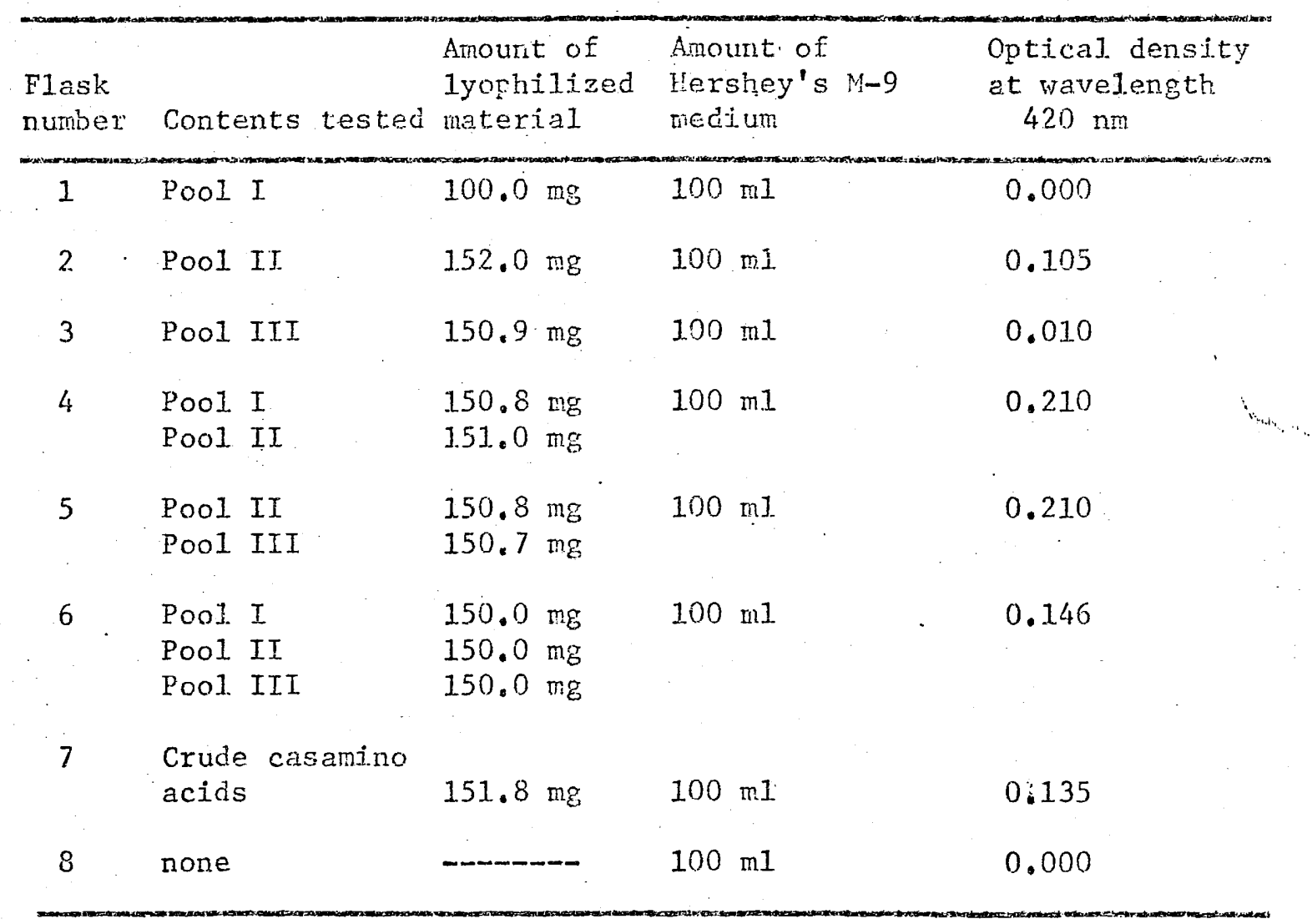




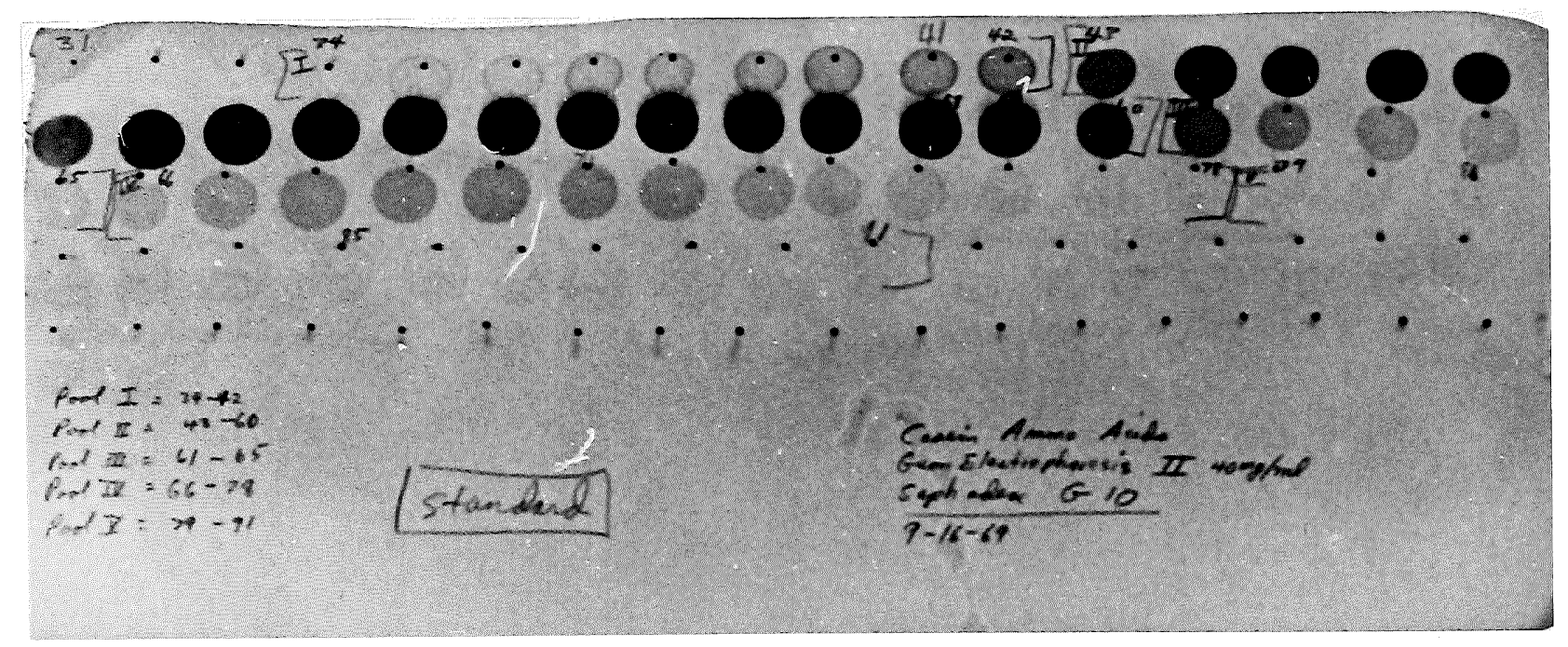

Figure 5. Standard spot-o-gram for casamino acids, Geon electrophoresis II, sephadex G10 fractions. 
Pseudomonas aerurinosa Ps-1C. As seen in Table VI, pool II best

contributed to enzyme production.

In order to determine which amino acids make up the pool II group from the sephadex treatment, a series of paper and thin layer chromatographs were made.

The first type of chromatography used was one dimensional paper chromatography of the five pools collected from the sephadex treatment of casamino acids, Geon electrophoresis, II, The resul.ts, as seen in Figure 6 show the comparison of the five pools, indicating a possible connection with the amino acids of glycine, hydroxy proline, alanine, proline, valine, phenylalanine, isoleucine and leucine, when conpared to results of Smith (1958). Pool II obviously contains most of the material, however it appears that pool $\mathrm{V}$ contains amino acids not found in pooi II.

One dimensional-thin layer chromatography of casamino acids, geon electrophoresis II, sephadex G-10 pool II apparently did contain the amino acids: proline, alanine, glycine, valine, leucine, hydroxyproline, aspartic acid, 1ysine, and glutamic acid as seen in Figures 7, 8, and 9 .

Two dimensional-thin layer chromatography of the sarie sample, using different solvent systems according to Pataki (1968), also indicated the same general results. See Figures 10,11 , and 12 .

Another attempt to determine which general group of amino acids contribute to the nutritional requirements for Ps-IC protease production, was nade by testing the amino acid grouping as outlined by Conn and Stumpf (1964). The monoamino-monocarboxylic amino acids, dicarboxylic amino acids, basic amino acids, aronatic amino acids, and the heterocyclic amino acicls were tested as substrate for enzyme production, and 
TABIE VI

SUBSTRATE TESTS OF CASAITINO ACIDS, CLON ELECTYOPHODESIS II, STPHADEX GJO POOLS

\begin{tabular}{lllll}
$\begin{array}{c}\text { Flask } \\
\text { set } \\
\text { number }\end{array}$ & $\begin{array}{l}\text { Sephadex } \\
\text { G10 pool } \\
\text { number }\end{array}$ & $\begin{array}{l}\text { Amount of } \\
\text { lyophilized } \\
\text { material }\end{array}$ & $\begin{array}{l}\text { Amount of } \\
\text { Hershey's } \mathrm{N}-9 \\
\text { medium }\end{array}$ & $\begin{array}{l}\text { Optical } \\
\text { density at } \\
\lambda 420 \mathrm{~nm}\end{array}$ \\
\hline 1 & I & $250 \mathrm{mg}$ & $100 \mathrm{~m} 1$ & 0.005 \\
2 & II & $250 \mathrm{mg}$ & $100 \mathrm{ml}$ & 0.065 \\
3 & III & $250 \mathrm{mg}$ & $100 \mathrm{ml}$ & 0.010 \\
4 & IV & $250 \mathrm{mg}$ & $100 \mathrm{ml}$ & 0.002 \\
5 & V & $250 \mathrm{mg}$ & $100 \mathrm{ml}$ & 0.000 \\
6 & Contro1 & none & $100 \mathrm{ml}$ & 0.000 \\
\hline
\end{tabular}




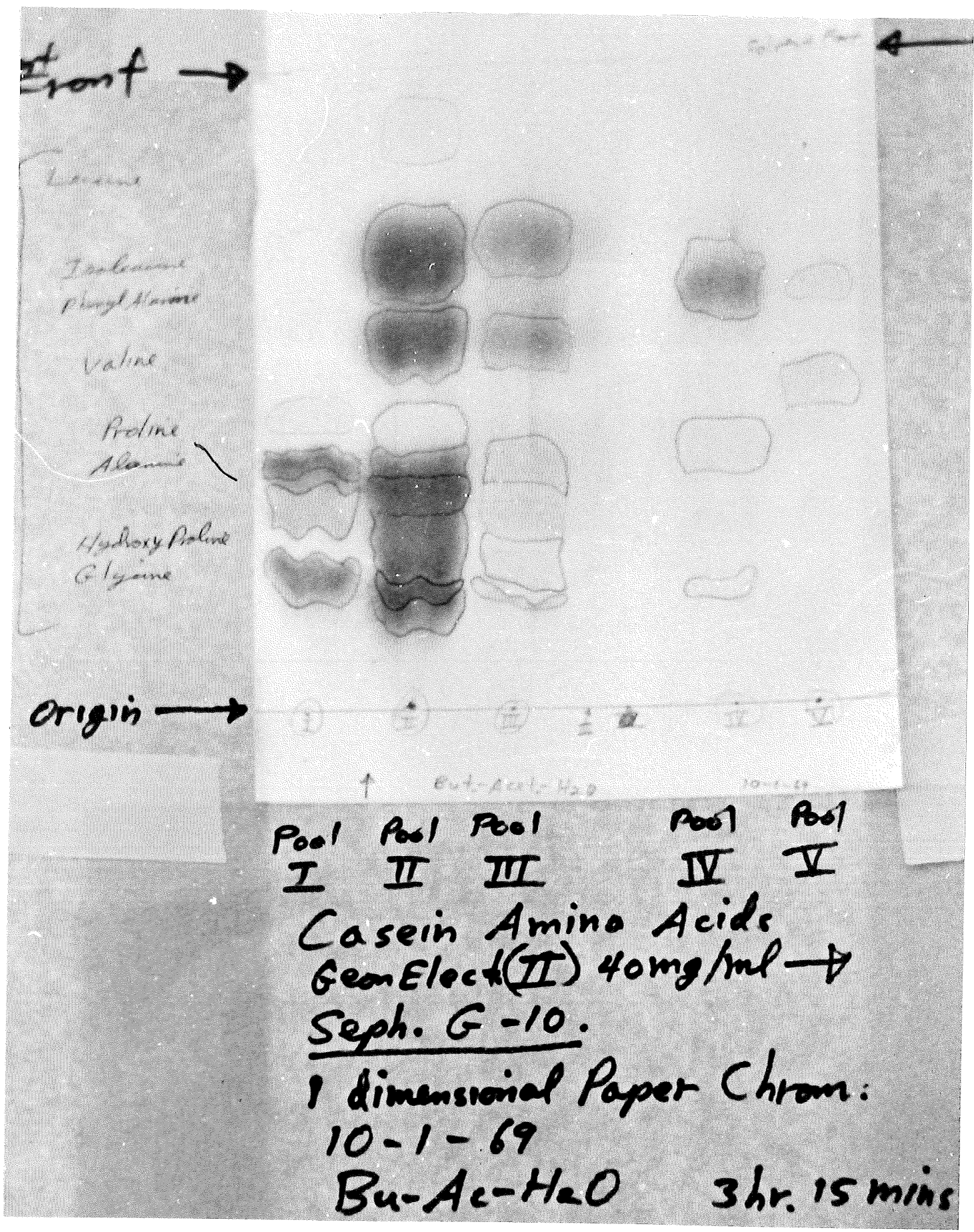

Figure 6. One dimensional paper chromatography of the five pools from sephadex G-10 treatment of casamino acids, Geon electrophoresis pool II. 


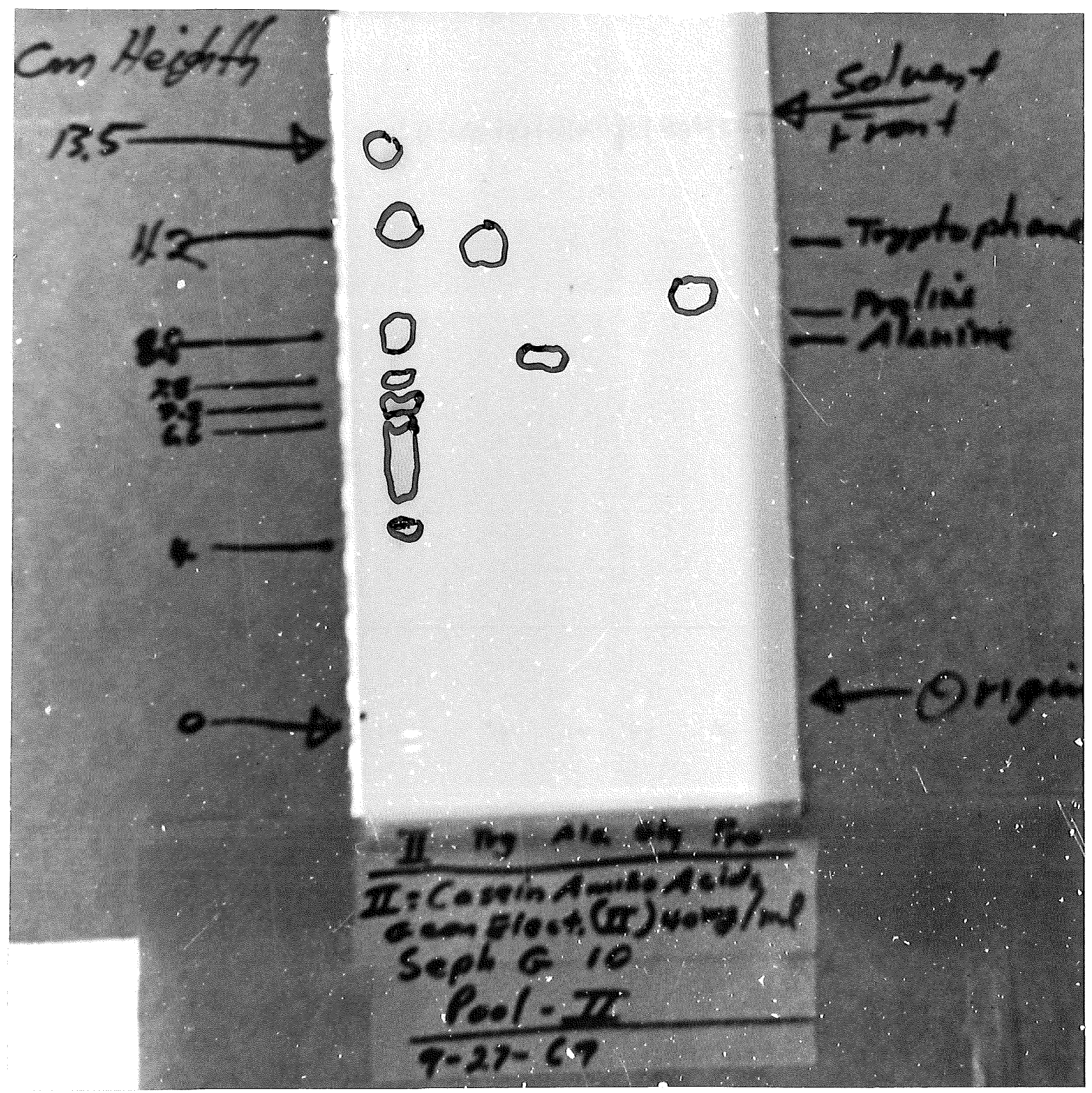

Figure 7. One dimensional thin layer chrmoatography of casamino acids, Geon electrophoresis II, sephadex G10 II. The solvent is butanol-acetic acid-water, $(4: 1: 5)$. 
Figure 8. One dirensional thin layer chromatography of casamino acids, Geon electrophoresis II, sephadex GIO II. The solvent is i....... butanol-acetic acidwater, $(4: 1: 5)$. 


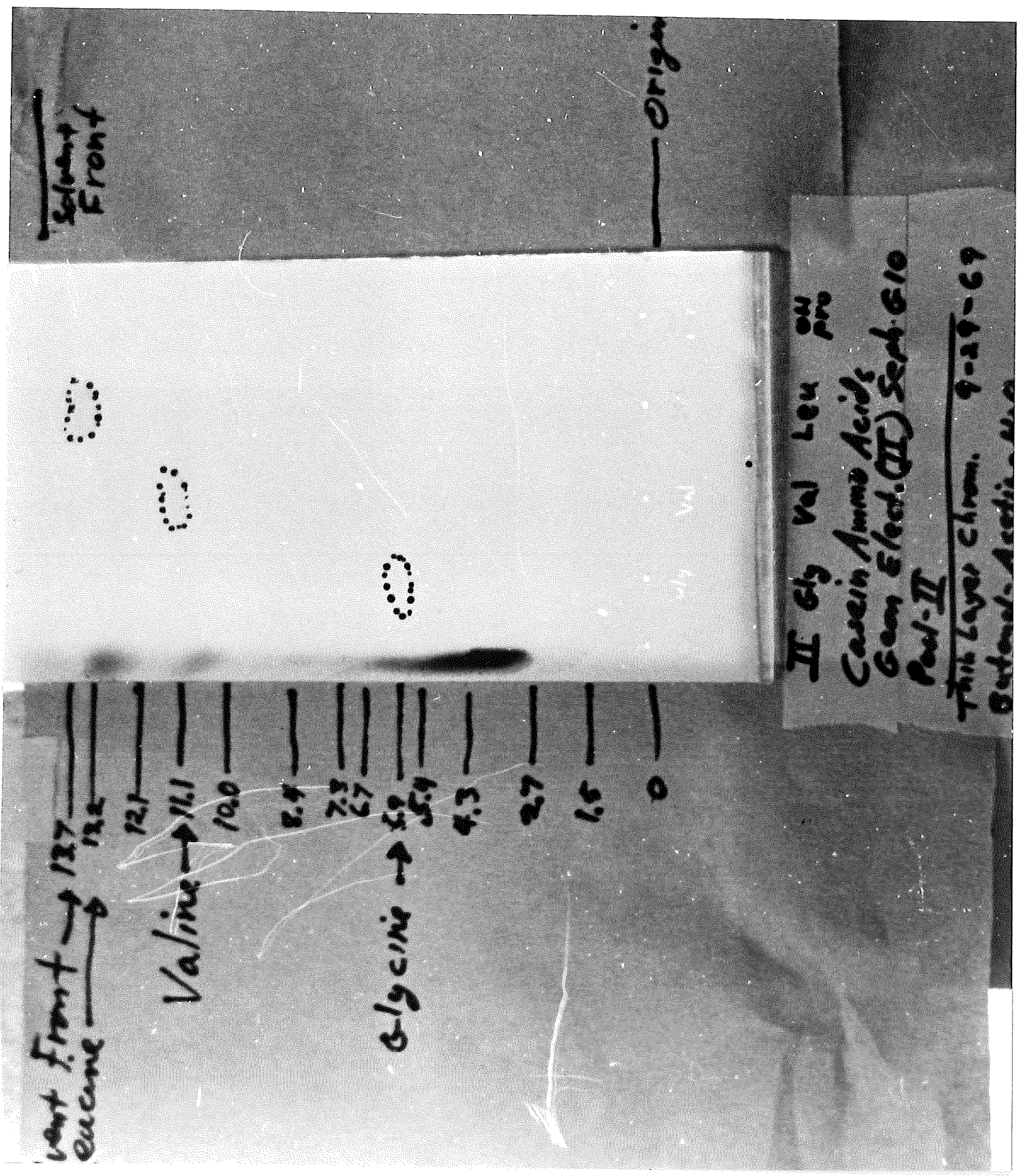




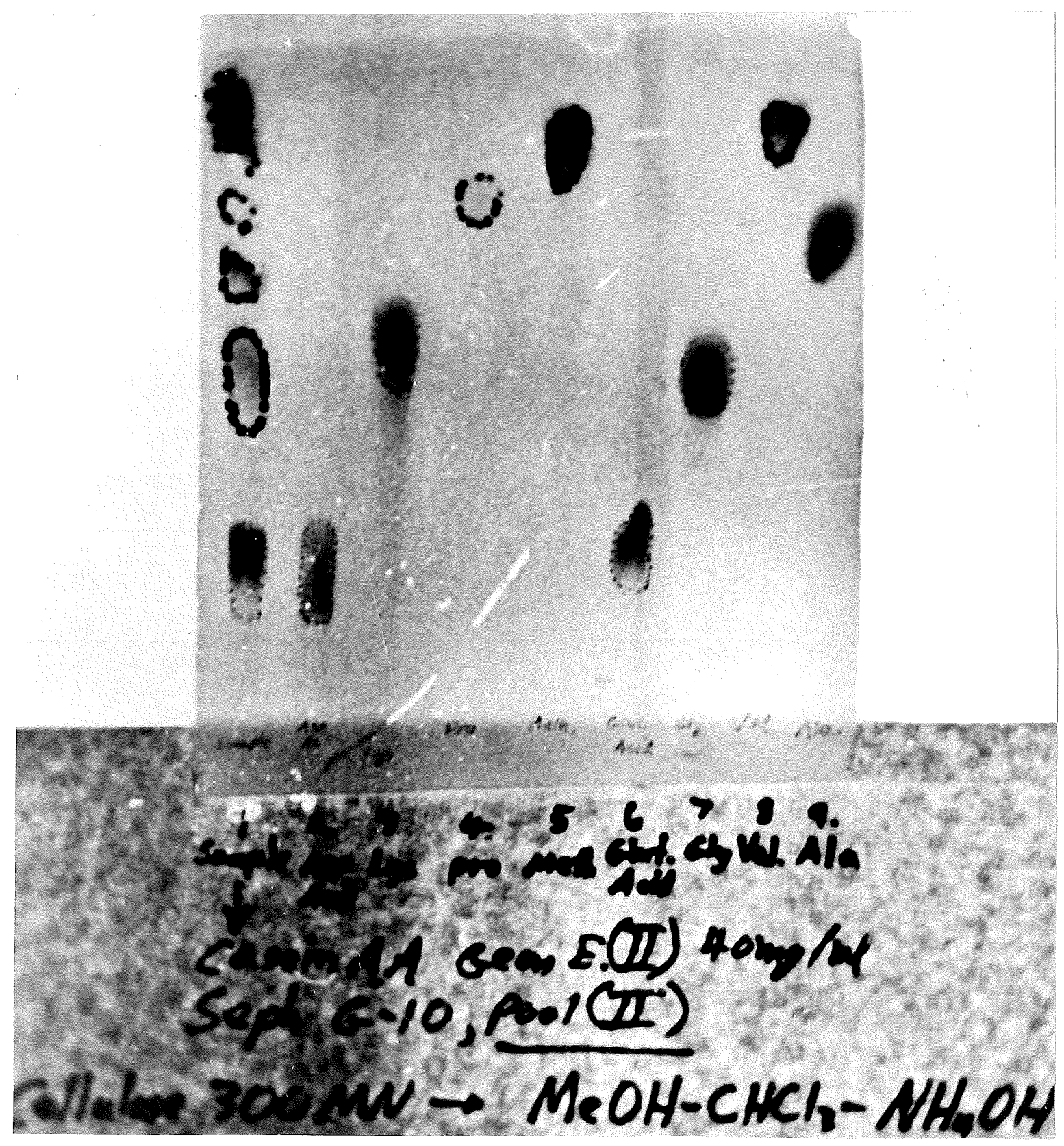

Figure 9. One dimensional thin layer chromatography of casamino acids, Geon electrophoresis II, sephadex G10 II. Solvent is methanol-chloroform-ammonia, $(2: 2: 1)$. 


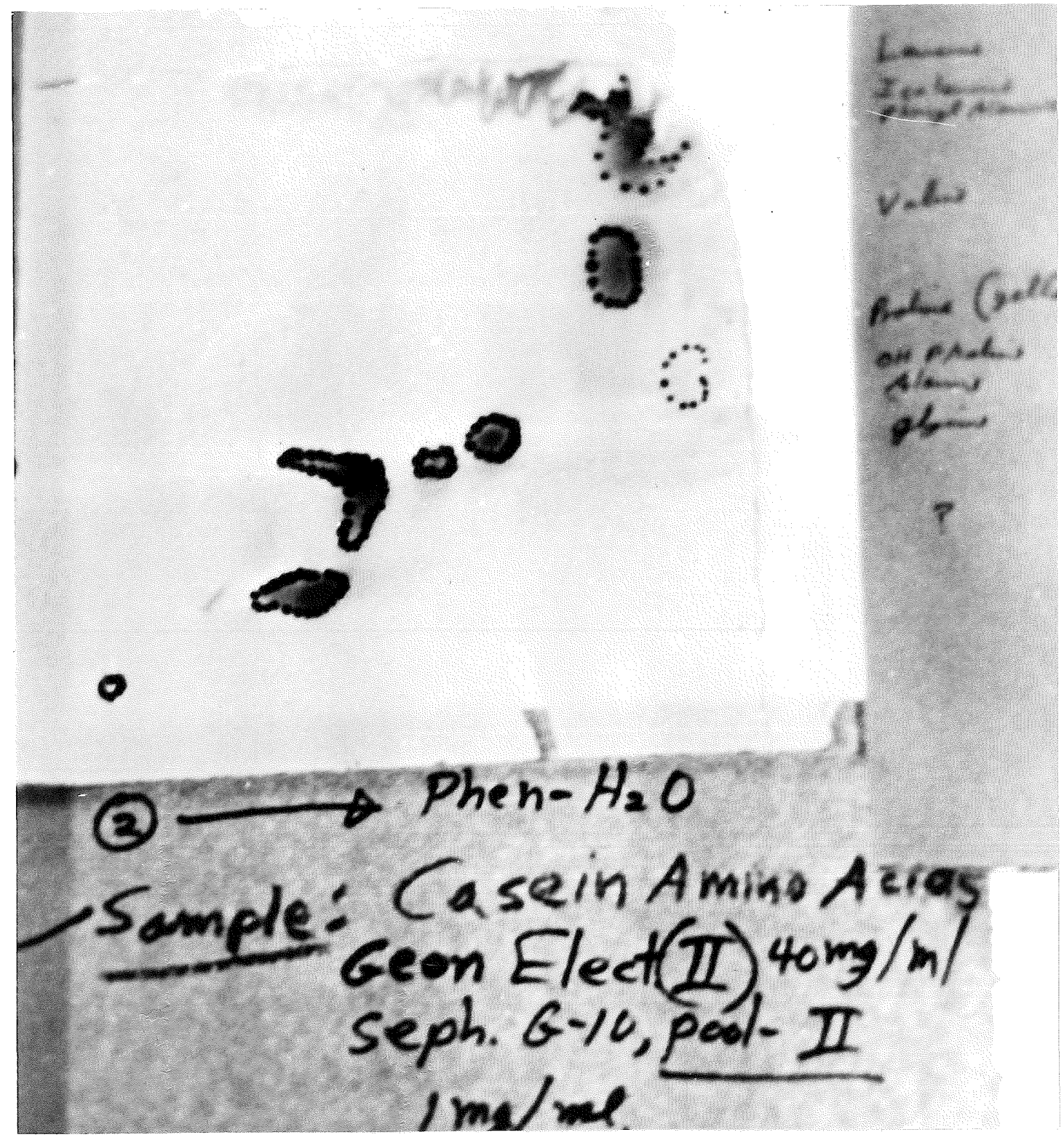

Figure 10. Two dimensional thin layer chromatography of casamino acids, Geon electrophoresis II, sephadex G10 II. The solvents are (1) butanol-acetic acid-water, $(4: 1: 5)$; (2) phenol-water, (4:1). 


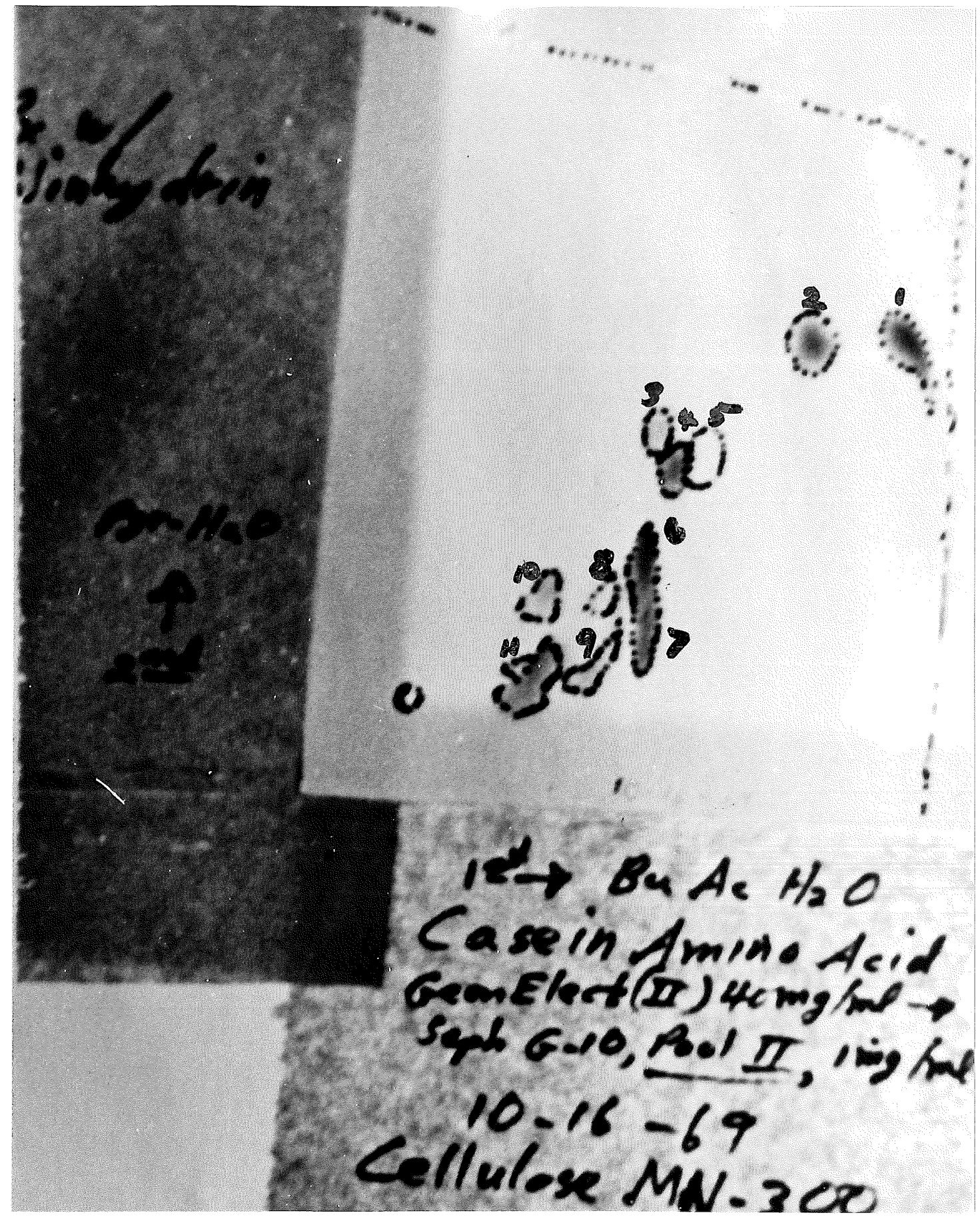

Figure 11. Two dimensional thin layer chromatography of casamino acids, Geon electrophoresis II, sephadex G10 II. The solvents are (1) methanol-chloroform-ammonia, $(4: 1: 5)$; (2) pyridine-water, (4:1)。 The spot numbers represent the following amino acids: (1) leucine, (2) isoleucine, (3) methionine, (4) valine, (5) phenylalanine, (6) alanine, (7) proline, (8) serine, (9) glycine and asparagine, (10) histidine, (11) cysteine and lysine. 


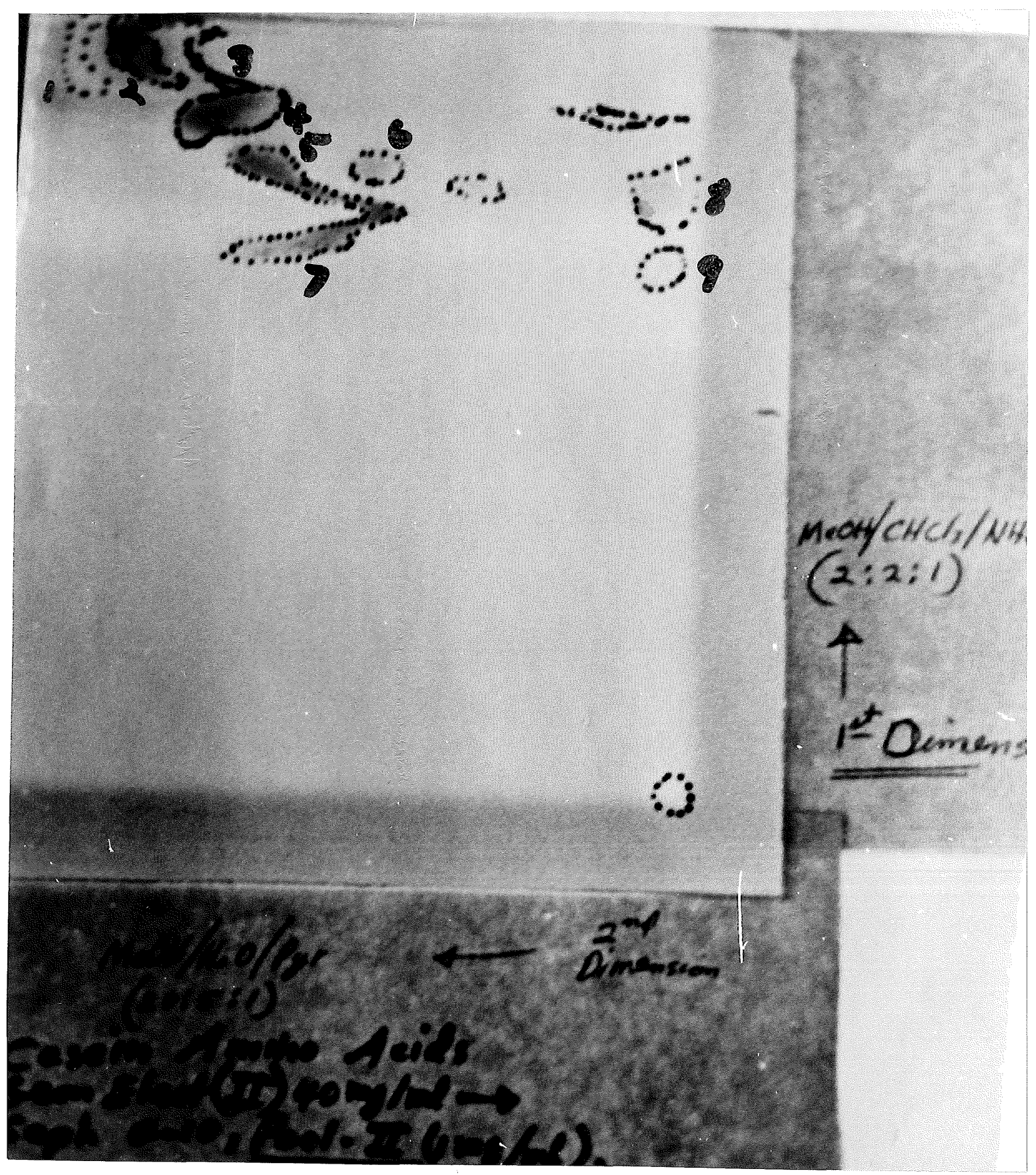

Figure 12. Two dimensional thin layer chromatography of casamino acids, Geon electrophoresis II, sephadex G10, pool II. The solvar ents are (1) methano1-chloroform-ammonia, $(2: 2: 1)$; (2) methanolwater-pyridine- $(20: 5: 1)$. The spot numbers represent the following amino acids: 1) valine, 2) isoleucine and leucine, 3) phenylalanine, 4) proline, 5) alanine, 6) glycine, 7) serine, 8) arginine, 9) lysine. 
as seen in Table VII, none of these significantiy contributed to protease production.

Anino Acid Combinations Tested as Substrate For Ps-1C Protease

Production: The amino acids: alanine, phenylalanine, levcine, isoleucine, proline, hydroxyproline, valine and glycine were employed ir various combinations in order to determine how nany, and which ones served as nutritional requirements to the bacterium for enzyme production. The step vise determination of the three required amino acids phenyalanine, isoleurine, and valine is seen in Tabies VTII, IX, $X$, and $\mathrm{XI}$. The mininal concentration for thaximur protease production for these amino acids were: $2.0 \mathrm{mg} / \mathrm{ml}$ for valine, 1.0 to $0.5 \mathrm{mg} / \mathrm{mI}$ for isoleucine, and $0.5 \mathrm{mg} / \mathrm{mI}$ for phenylalanine. See Tables XII, XIII, and XIV.

Inhibition by excess amino acid was tested, and it was deterniners that isoleucine in excess concentrations, i.e. greater than $1.0 \mathrm{mg} / \mathrm{ml}$, did inhibit protease production, as seen in Table $X V$.

\section{Divalent Metal Ion Requirenetit}

The divalent metal ions tested as nutritional requirements for enzyme production at various concentrations were nagnesium, calcium, cobalt, copper, and zinc. Oniy magnesium ion alloved good enzyne production, of which the maxinum enzyme production was at the magnesiun concentraion of $10^{-2} \mathrm{M}$, see Figure 13 .

\section{Growth Curves}

Grovth Curve of Eseuciomonas aeruginosa Is-IC as Correlated to Optical Density at Wavelenoth $660 \mathrm{~nm}$. There was no measurable lag phase in this experiment, hovever the data as plotted in Figure 14. does 
TABLE VII

SUBSTRATE TESTS OF GENERAL, AMINO ACID GROUPS FOR ENZYME PRODUCTION

\begin{tabular}{|c|c|c|}
\hline $\begin{array}{l}\text { Flask } \\
\text { set } \\
\text { number }\end{array}$ & $\begin{array}{l}\text { Amino acids } \\
\text { and } \\
\text { groups tested }\end{array}$ & $\begin{array}{l}\text { Optical density } \\
\text { at wavelength } \\
\quad 420 \mathrm{~nm}\end{array}$ \\
\hline$I$ & $\begin{array}{l}\text { Monamino and monocarboxyl: } \\
\text { alanine, valine, leucine, iso- } \\
\text { leucine, serine, threonine, } \\
\text { cysteine, and methionine }\end{array}$ & 0.000 \\
\hline II & $\begin{array}{l}\text { Dicarboxylic: } \\
\text { glutamic acid, aspartic } \\
\text { acid }\end{array}$ & 0.015 \\
\hline $\operatorname{III}$ & $\begin{array}{l}\text { Besic: } \\
\text { lysine, histidine, } \\
\text { asparagine }\end{array}$ & 0.010 \\
\hline IV & $\begin{array}{l}\text { Aromatics: } \\
\quad \text { phenylalanine, tyrosine }\end{array}$ & 0.012 \\
\hline $\mathrm{V}$ & $\begin{array}{l}\text { Heterocyclics: } \\
\text { histidine, tryptophane, proline, } \\
\text { hydroxyproline }\end{array}$ & 0.012 \\
\hline VI & None - control & 0.000 \\
\hline
\end{tabular}

Ten $\mathrm{m} 1$ of each $0.01 \%$ amino acid to be tested was added to a flask and then made up to $100 \mathrm{ml}$ aliquots with Hershey's M-9 medium with $0.01 \%$ dextrose. The culture flasks were inoculated frow a starter culture, incubated for 14 hours on a shaker at $37^{\circ}$ centigrade, and assayed for proteolytic activity. 
TABLE VIII

AMTNO ACIDS CORBINATIONS-I. TESTED AS

NUTRITIONAL REOUIREYENTS FOR

PS-1C PROTEASE PRODUCTION

\begin{tabular}{|c|c|c|c|c|c|c|c|}
\hline $\begin{array}{l}\text { Optical } \\
\text { density }\end{array}$ & 0.010 & 0.1 .50 & 0.105 & 0.028 & 0.087 & 0.190 & 0.150 \\
\hline $\begin{array}{l}\text { Flask } \\
\text { numbers }\end{array}$ & 1 & 2 & 3 & 4 & 5 & 6 & 7 \\
\hline \multirow{8}{*}{$\begin{array}{l}\text { Amino } \\
\text { acids } \\
\text { tested }\end{array}$} & \multirow{8}{*}{$\begin{array}{l}\text { none } \\
\text { con- } \\
\text { trol }\end{array}$} & ala & ala & $\ldots$ & ala & $-\infty$ & $150 \mathrm{mg}$ \\
\hline & & $\mathrm{Ph}-\mathrm{A}$ & Ph-A & $-\cdots$ & $-\infty$ & $P h-A$ & of crude \\
\hline & & leu & $-\infty$ & leu & lev & --- & casamino \\
\hline & & IsoL & $\cdots$ & IsoL & $-\infty$ & IsoL & acids \\
\hline & & pro & $\ldots$ & pro & pro & $-\cdots$ & \\
\hline & & $\mathrm{OH}-\mathrm{P}$ & $--n$ & $\mathrm{OH}-\mathrm{P}$ & $-m$ & $\mathrm{OH}-\mathrm{P}$ & \\
\hline & & val & val & $-\infty-\infty$ & val & val & \\
\hline & & gly & $g 1 \mathrm{y}$ & $-\cdots$ & gly & $g 1 y$ & \\
\hline
\end{tabular}

Each amino acid tested was added in $150 \mathrm{mg}$ amounts to 100 m1 aliquots of Hershey's $1-9$ mediun with $0.05 \%$ dextrose. The test flasks were inoculated from a starter culture, incubated for 14 hours at $37^{\circ} \mathrm{C}$ on a shaker, and assayed for proteolytic activity. The optical density readings are at wavelength $420 \mathrm{~nm}$, and the abbreviations used are as follows: ala=alanine; $P h-A=p h e n y 1-$ alanine; leu=leucine; pro=proline; $\mathrm{OH}-\mathrm{P}=$ hydroxyproline; $\mathrm{Val}=\mathrm{val}$ -

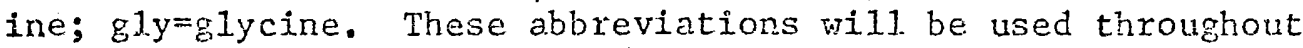
the following tables. 
TABLE IX

AMINO ACID COMBINATIONS-II TESTED AS
NUTRITTONAL REQUIREYENTS FOR
PS-1C PROTEASE PRODUCTION

\begin{tabular}{|c|c|c|c|c|c|c|c|c|}
\hline $\begin{array}{l}\text { Optical } \\
\text { density }\end{array}$ & 0.100 & 0.253 & 0.034 & 0.031 & 0.028 & 0.022 & 0.050 & 0.058 \\
\hline $\begin{array}{l}\text { Flask } \\
\text { numbers }\end{array}$ & 1 & 2 & 3 & 4 & 5 & 6 & 7 & 8 \\
\hline \multirow{7}{*}{$\begin{array}{l}\text { Amino } \\
\text { acids } \\
\text { tested }\end{array}$} & $P h-A$ & $P h-A$ & $\mathrm{Ph}-\mathrm{A}$ & $\mathrm{Ph}_{1}-\mathrm{A}$ & $P h-A$ & 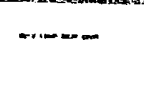 & $\ldots$ & $\cdots$ \\
\hline & IsoL & Isol & IsOL & Isot & Isot & IsoI & Isot & Isol \\
\hline & OH-P & $\mathrm{OH}-\mathrm{P}$ & $\mathrm{OH}-\mathrm{P}$ & OII $-\mathrm{D}$ & $\mathrm{OH}-\mathrm{P}$ & $\mathrm{OH}-\mathrm{P}$ & $\mathrm{OH}-\mathrm{P}$ & $\mathrm{OHI}-\mathrm{P}$ \\
\hline & va1 & val & $-\cdots$ & $-\cdots-$ & $-\infty$ & $-m-\infty$ & val & val \\
\hline & gly & $\cdots$ & gIy & $-\infty \cdots$ & $-\infty-\infty$ & gly & $-\infty$ & gl.y \\
\hline & $\cdots$ & $m-\infty$ & $-\infty$ & $-\infty-$ & pro & pro & pro & pro \\
\hline & ..... & $-m$ & $-\infty$ & $-\infty-\infty$ & $-\infty-$ & 1eu & leu. & Ieu \\
\hline
\end{tabular}

Each amino acid tested was adcied in $1.50 \mathrm{mg}$ amounts to $50 \mathrm{ml}$ aliquots of Herchey's $M-9$ medium with $0.05 \%$ dextrose. The test flasks were inoculated from a starter culture, incubated for 14 hours at $37^{\circ} \mathrm{C}$ on a shaker, and assayed for proteolytic activity. The optical density readings are at wavelength $420 \mathrm{~nm}$. 
TABLE X

AMINO ACID COMBINATIONS --III TESTED AS NUTRITIONAL REQUIREMTNTS FOR

PS-1C PROTEASE PRODUCTION

\begin{tabular}{|c|c|c|c|c|c|c|c|}
\hline $\begin{array}{l}\text { Optical } \\
\text { density }\end{array}$ & 0.323 & 0.040 & 0.485 & 0.191 & 0.400 & 0.13 .3 & 0.013 \\
\hline $\begin{array}{l}\text { Fiask } \\
\text { numbers }\end{array}$ & 1 & 2. & 3 & 4 & 5 & 6 & 7 \\
\hline \multirow{4}{*}{$\begin{array}{l}\text { Anjino } \\
\text { acids } \\
\text { tested }\end{array}$} & $P^{\prime}-A$ & $\mathrm{Pil}-\mathrm{A}$ & $P h-A$ & Fh-A & $-\infty$ & $600 \mathrm{Ing}$ & none \\
\hline & IsoL & ISOL & IsoL & $\ldots$ & IsoL & crude & control \\
\hline & $\mathrm{OH}-\mathrm{P}$ & $\mathrm{OH}-\mathrm{P}$ & $-\cdots$ & $\mathrm{OH}-\mathrm{P}$ & $\mathrm{OH}-\mathrm{P}$ & casamino & \\
\hline & val & $-\infty$ & val & val & val & acids & \\
\hline
\end{tabular}

Each amino acid tested was added in $150 \mathrm{mg}$ amounts to 1.00 m1 aliquots of liershey's $M-9$ medium with $0.05 \%$ dextrose. The test flasks were inoculated from a starter culture, incubated for 14 hours at $37^{\circ} \mathrm{C}$ on a shaker, and assayed for proteolytic activity. The optical density readings are at vavelength $420 \mathrm{~nm}$, and are the average of tivo experiments. 
TABIE XI

AMINO ACID COMBINATTONS-IV TESTED AS NUTRITIONAL REQUIRENENTS FOR

PS-1C PROTEASE PRODUCTION

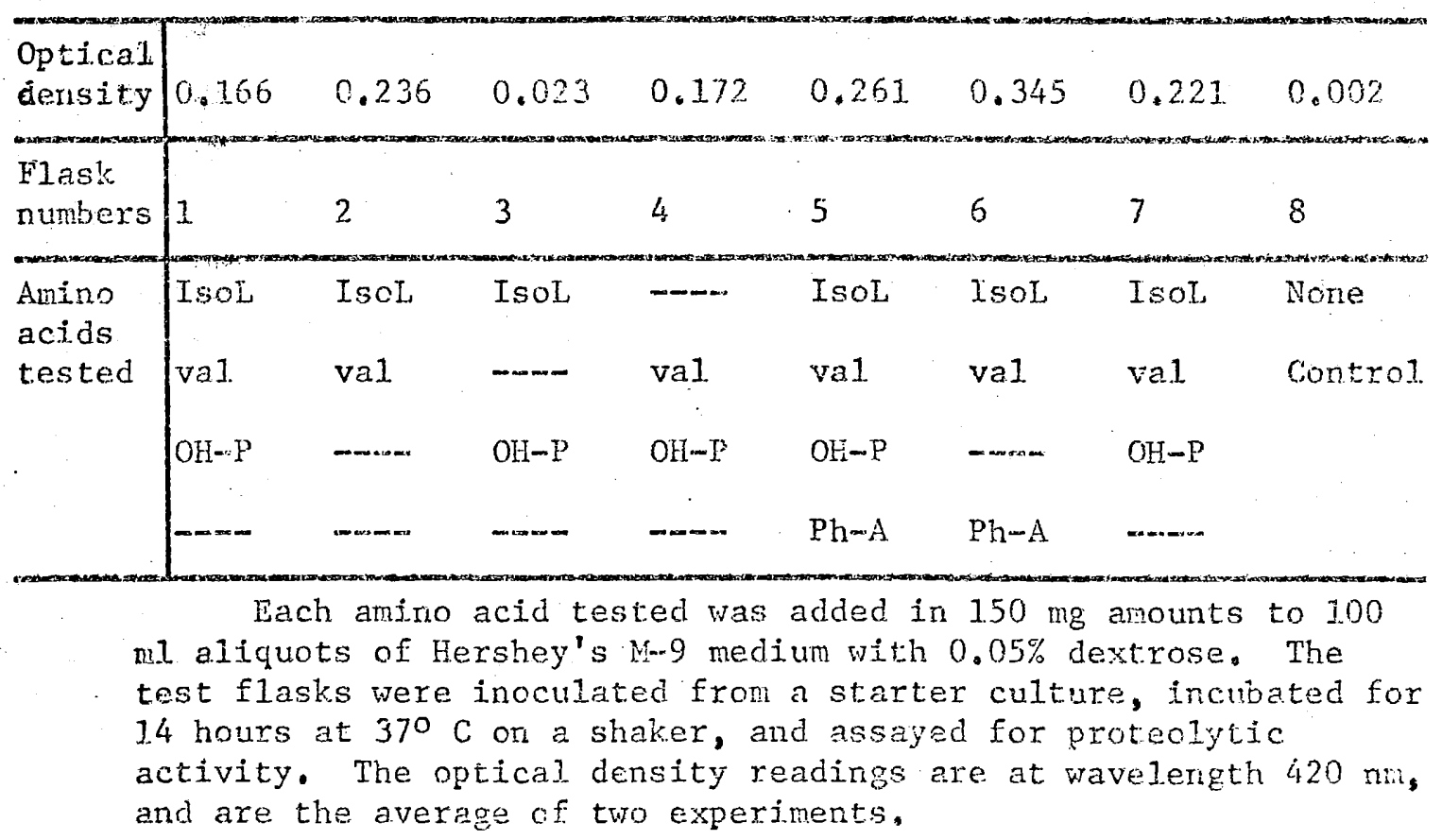


TABLE XII.

ISOLEUCINE CONCENTRATION REQUIRENENT

FOR PS-1C PROTEASE PRODUCTION

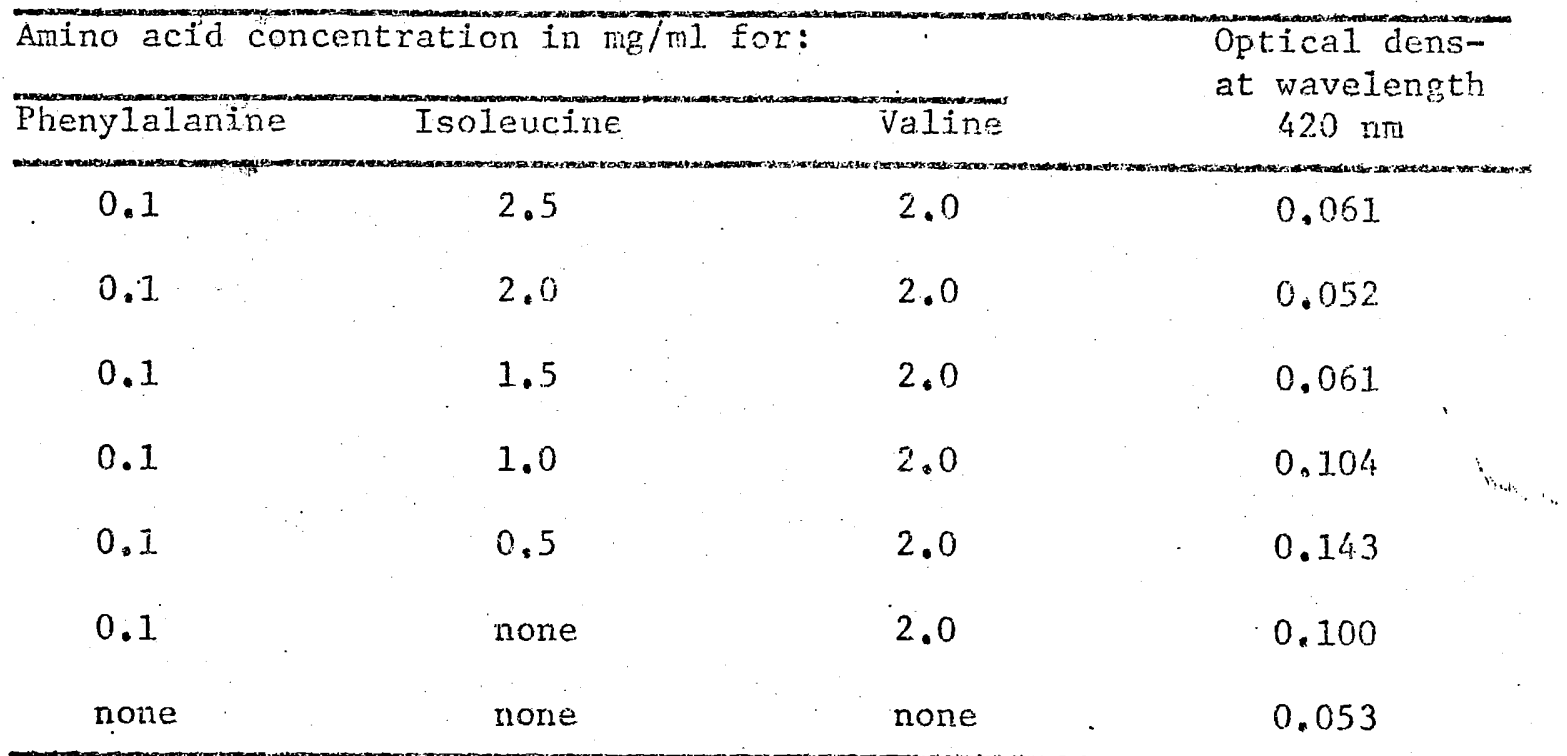

The culture medium consisted of $10 \mathrm{ml}$ aliquots of Hershey's M-9 medium with $0,05 \%$ dextrose. The test tubes were inoculated from a starter culture, incubated at $37^{\circ}$ on a shaker, and assayed for proteolytic activity. The optical density readings are the average of two experiments. 
TABLE XIII

PHENYLALANINE CONCENTRATION REOUIREMENT

FOR PS-IC PROTEASE PRODUCTION

\begin{tabular}{|c|c|c|c|}
\hline \multicolumn{3}{|c|}{ Amino acid concentration in $\mathrm{mr} / \mathrm{ml}$ for: } & \multirow{2}{*}{$\begin{array}{l}\text { Optical dens- } \\
\text { ity at wave- } \\
\text { length } 420 \mathrm{~nm}\end{array}$} \\
\hline Phenylalanine & Isoleucine & Valine & \\
\hline 1,0 & 1.0 & 2.0 & 0.084 \\
\hline 0.5 & 1.0 & 2.0 & 0.087 \\
\hline 0.1 & 1.0 & 2.0 & 0.056 \\
\hline 0.05 & 1,0 & 2.0 & 0.054 \\
\hline none & 1.0 & 2.0 & 0.049 \\
\hline none & rione & none & 0.018 \\
\hline $\begin{array}{l}\text { M-9 medi } \\
\text { from a s } \\
\text { ed for ? } \\
\text { average }\end{array}$ & $\begin{array}{l}\text { ture medium } \\
\text { th } 0.05 \% \text { dex } \\
\text { culture, } \\
\text { lytic activi } \\
\text { experinent }\end{array}$ & $\begin{array}{l}\text { of } 10 \mathrm{~m} \\
\text { he test } \\
\text { at } 37^{\circ} \mathrm{c} \\
\text { optical }\end{array}$ & $\begin{array}{l}\text { is of Hershey's } \\
\text { re inoculated } \\
\text { aker, and assay- } \\
\text { readings are the }\end{array}$ \\
\hline
\end{tabular}


TABLF YTV

VALINE CONCENTRATION REQUTREMENT FOR PS-IC PROTEASE PRODUCITON

\begin{tabular}{|c|c|c|c|}
\hline \multicolumn{3}{|c|}{ Amino acid concentration in $\mathrm{mg} / \mathrm{ml}$ for: } & \multirow{2}{*}{$\begin{array}{c}\text { Optical density } \\
\text { at wavelength } \\
420 \mathrm{~nm}\end{array}$} \\
\hline Phenylalanine & Isoleucine & Valine & \\
\hline 0.1 & 2.0 & 2.0 & 0.108 \\
\hline 0.1 & 2.0 & 1.5 & 0.078 \\
\hline 0.1 & 2.0 & 1.0 & 0.077 \\
\hline 0.1 & 2.0 & 0.5 & 0.041 \\
\hline 0.1 & 2.0 & 0.1 & 0.009 \\
\hline 0.1 & 2.0 & none & 0.007 \\
\hline none & none & none & 0.003 \\
\hline
\end{tabular}

The culture medium consisted of $10 \mathrm{~m} 1$ aliquots of Hershey's M-9 medium with $0.05 \%$ dextrose. The test tubes were inoculated from a starter culture, incubated at $37^{\circ} \mathrm{C}$ on a shaker, and assayed for proteolytic activity. The optical density readings are the average of two experinents. 
TABLE XV

TESTS FOR INHIBTTION BY EXCESS
REQUTRED ANINO ACID

\begin{tabular}{|c|c|c|c|c|c|}
\hline $\begin{array}{l}\text { Tube set } \\
\text { number }\end{array}$ & $\begin{array}{l}\text { Arrino acid } \\
\text { Isoleucine }\end{array}$ & $\begin{array}{c}\text { concentra } \\
\text { Valine }\end{array}$ & $\begin{array}{l}\text { ns in } \mathrm{mg} / \mathrm{ml}: \\
\text { Pherylalaning }\end{array}$ & Corment & $\begin{array}{l}\text { Optical } \\
\text { density }\end{array}$ \\
\hline . & 1.0 & 2.0 & 0.1 & $\begin{array}{l}\text { al1. are } \\
\text { minjmal }\end{array}$ & 0.065 \\
\hline$I I$ & 2.0 & 2.0 & 0.1 & $\begin{array}{l}\text { excess } \\
\text { isoleucine }\end{array}$ & 0.043 \\
\hline III & 1.0 & 2.0 & 2.0 & $\begin{array}{l}\text { Excess } \\
\text { phenylalanine }\end{array}$ & 0.144 \\
\hline IV & 2.0 & 2.0 & 2.0 & $\begin{array}{l}\text { excess } \\
\text { isoleucine, } \\
\text { phenylalanine }\end{array}$ & 0.055 \\
\hline V & none & none & none & control & 0.053 \\
\hline
\end{tabular}




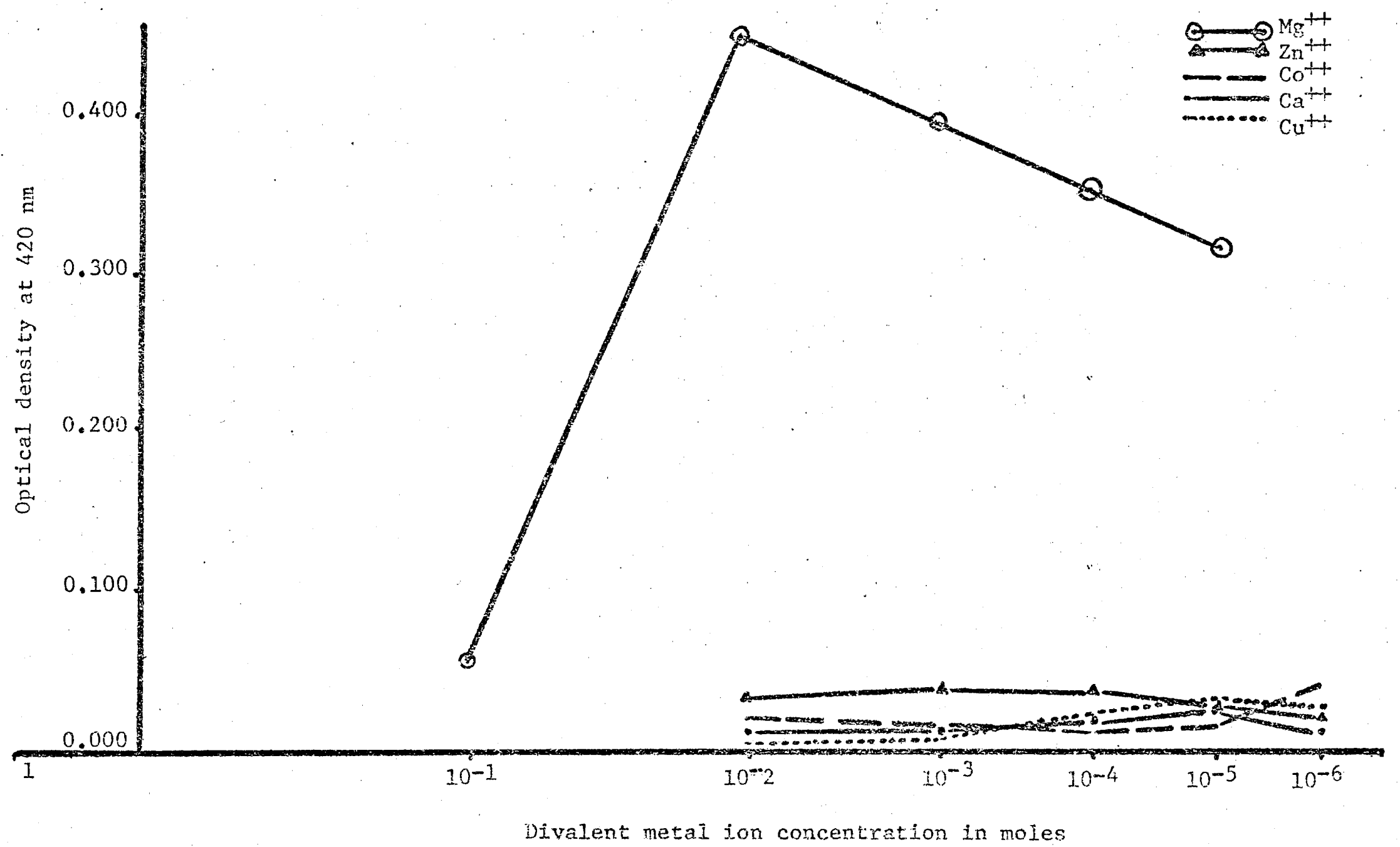

Figure 13. Comparison of metal fon concentration requirement for Ps-1C protease production. 


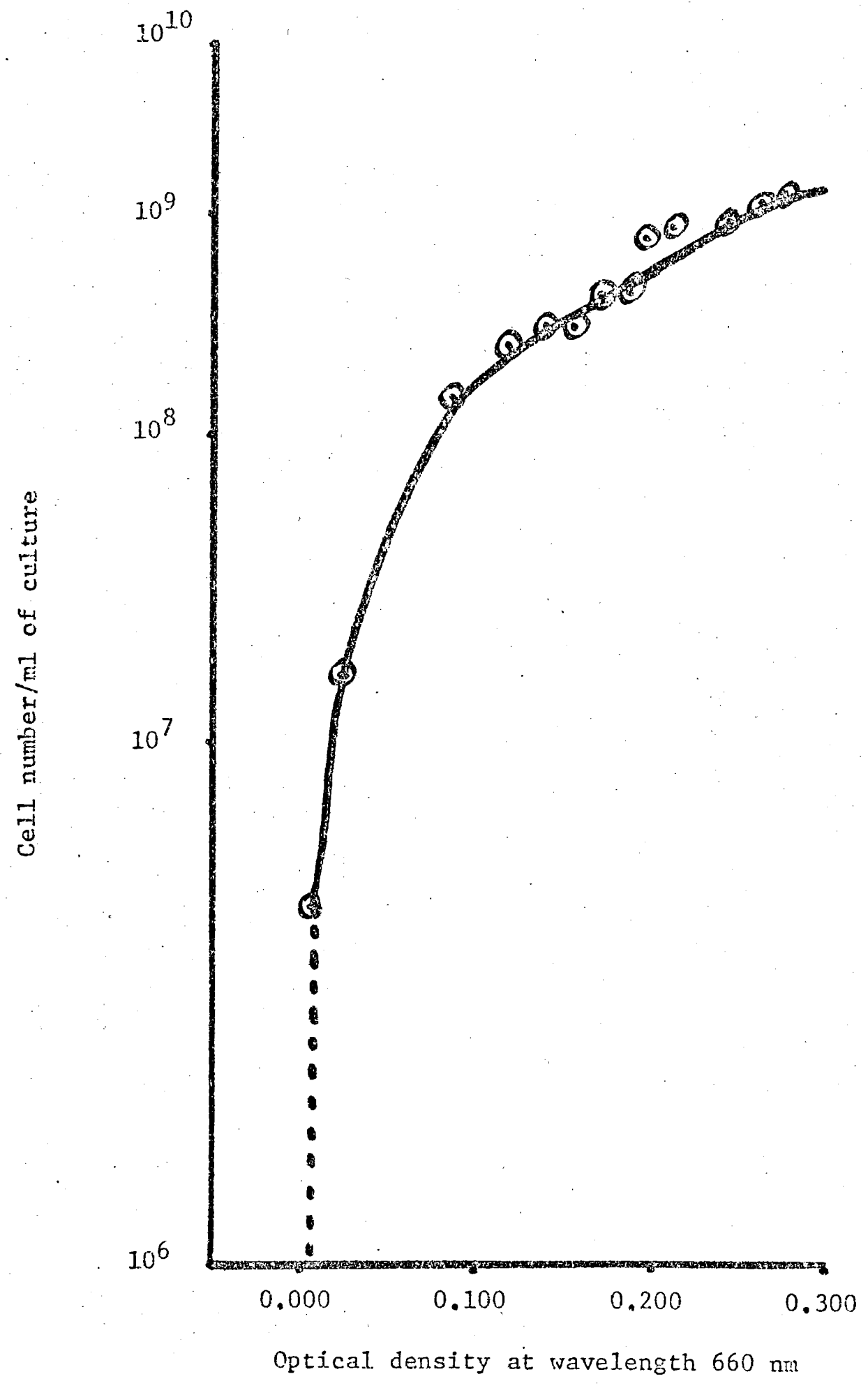

Figure 14. Growth verses optical density at wavelength $660 \mathrm{~nm}$, for Pseudomonas aeruginosa, Ps-1C in nutrient broth-yeast extract. 
give adequate information for determining the number of viable cells per m.1 of starter culture at time of inoculation into test medias. All dilutions of the plate counts at zero time were confluent in growth,

and therefore no calculations for cell number was posstble. However

- most of the remaining data was consistent.

3. Growth and Protease Production Versus Time Protease production

Abegan in mid-log phase of growth and continued throughout log phase

Fand into stationary phase. The enzyne activity leveled off somentret

wafer 18 hours of growth, but again increased sisghty after 20 hours. See F'gure 15. 


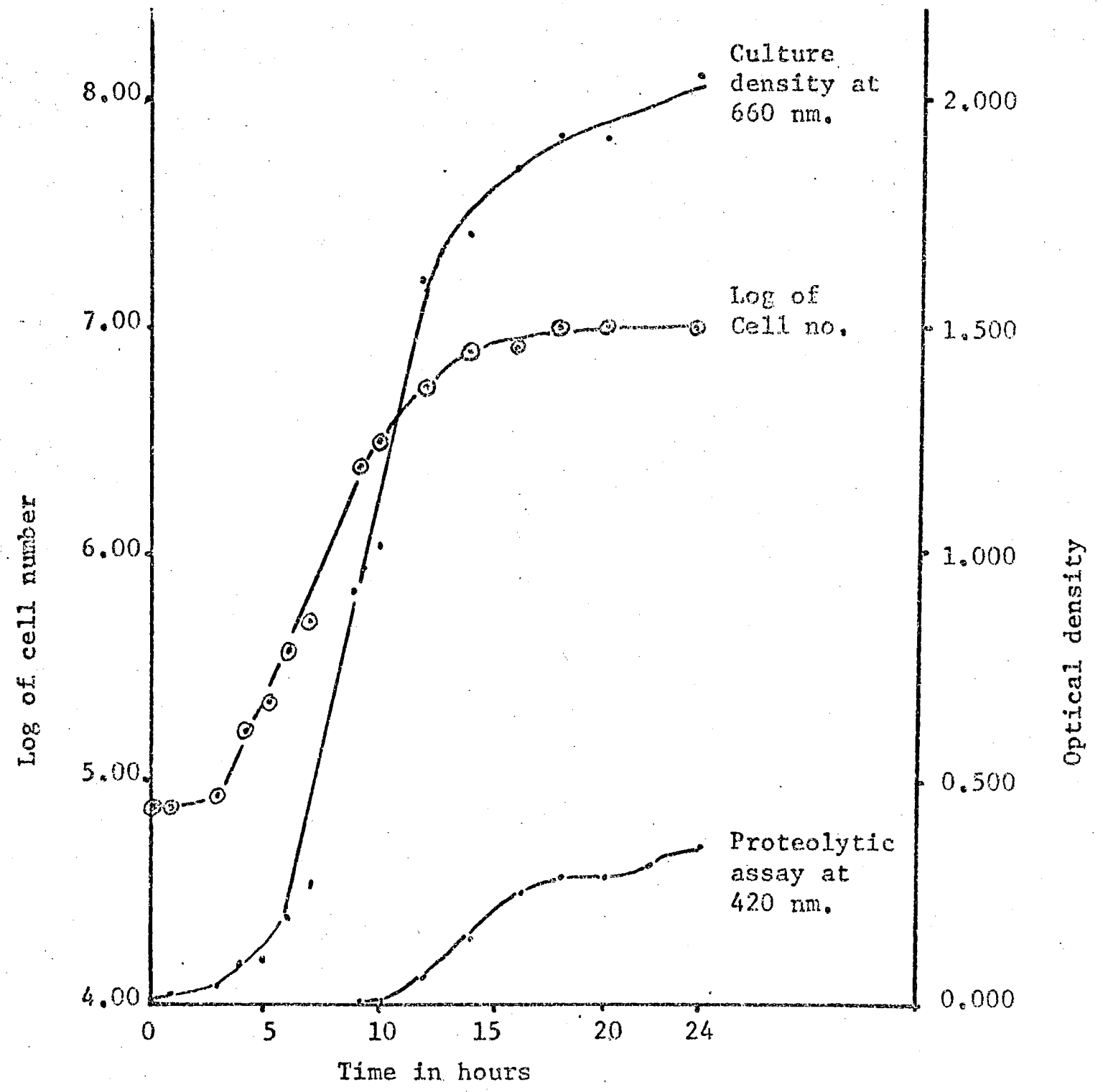

Figure 15. Growth and Frotcase production versus time in Pseudomonas aeruginosa, Ps-IC. 


\section{DISCUSSION}

\section{Glucose Inhibition of Protease Production}

At concentrations greater than $0.05 \%$, glucose, a rapidly

matabolized carbohylrate, apparently inhjibits or represses enzyme

production, but not necessarily growth. Other investigators have had

similar results; Litchfield and Prescott (1970), Keen and Wi11iams (1967)

using sucrose and Pseudomonas lachrymans, Norton and Sokatch (1966) also

noted that when Iseudomonas aeruginosa was grow on giucose, that the

inducible enzyne which catalyzes D-valíre oxidation was somehow inhibited.

\section{Proteose Peptone Analysis}

Earlier work in the laboratory of Dr. E. Fisher, Ir. (1969)

(Unpublished results) indicated that proteose peptone allowed the best

enzyme production out of five different undefined medias tested. Ilovever

the only significant thing obtained from the separation techniques

applied to proteose peptone was that this media probably contained a

larse number of amino acids which may have contributed to enzyme

production, Figure 4 .

Amino Aciá Analysis

Various investigators have noted that specific amino acias are required for enzyme production in many different organisns: (Litchfield and Prescott, 1970; Hamel and Zimmerman, 1966; Norton and Sokatch, 1966)

The results in this paper indicate that Pseudomonas aeruginosa Ps-1C does in fact require the presence of the three awino acids listed in their respective concentrations for maximum protease production in Hershey's $M-9$ media. However, the results also indicate, in Tables $X, X I$, and XIT, 
that there may be some competition between isoleucine and hydroxyprolire, although when tested individually isoleucine does allor greater proteolytic activity to take place than does hydroxyproline. The effect of hydroxyproline cannot be ignored since it is an important constituent of collagen. Although in structure isoleucine and hydroxyproline appear to be very dissinilar, a-ketoglutarate is a comon constituent to the biosynthesis of both amino acids, and this in some way may be involved with competition between them, as a nutritional requirement for induction of Ps-1.C protease.

Atthough isoleucine appears to be required for enzyme production, it also acts as an inhibitor at concentrations greater than $1.0 \mathrm{mg} / \mathrm{ml}$. Sashital and Zimmernan (1968) also indicated that isoleucine and four other amino acids specifically and individually repressed the formation of the induced extracellular protease of Streptococcus faecalis var. Liquefaciens.

McDonald and Chambers $\left(196 \theta^{\prime}\right)$ in studying the regulation of proteinase formation in a Micrococcus sp. concluded that because extracellular proteinase formation is induced by anino acids and suppressed by various carbon sources, and begause the organism can utilize amino acids as carbon sources for growth, therefore the function of extracellular proteinase of this organism is to ensure a supply of carbon for growth rather than a supply of amino acids for protein synthesis. It has already been documented that Pseudomonas aeruginosa can utilize amino acids e.g. valine, as carbon source and nitrogen source. This study may indicate that the three amino acids presence does induce enzyne production, or at least allows the nutritional requirements for it to accur; and enzyne production is suppressed when concentrations of 
dextrose are greater than $0.05 \%$. However it seems to me that the function of the enayne could encompass both aspects: to ensure a supply of carbon for growth, and to provide a supply of amino acids for protein synthesis.

Divalent Metal Ion Requirement

Previous experiments by Fisher (1960) indicated that chelating agents greatly reduced enzyme activity by Pseudomonas aeruginosa Ps-1C. Other protejuases of fevdomonas aeruginosa bave beev shown to requite divalent ions, (Morihara, 1963; Marvin, et. al, 1969). Therefore it was no sumrise to determine that $\mathrm{Mg}^{+1}$ was required for $\mathrm{Ps} \times 1 \mathrm{C}$ protease production, while calcium, cobalt, copper, and zino inhibited production of enzyme as well as growth in some cases, Figure 13.

Proteinases from other organisms also require divalent metal ions such as $\mathrm{zn}^{\mathrm{t}}$ required for protease secretion by Streptococcus faecilis (Casas and Zimnerman, 1959), and the $\mathrm{Mg}^{++}$required for the peptidases of E. coli. Proteus, Pseudomonas fjuorescens and Pseludomonas tumefaciens, (Berger, Johnson, and Peterson, $1938 \mathrm{a}, \mathrm{b}$ ), and the $\mathrm{Ca}^{\mathrm{t}}$ requirement for the clostridial collagenase (Gallop, sejfter, and Meilman, 1957; Mand1, Kellex, and Manahan, 1964)。

\section{Enzyme Production Versus Growth}

The results of Figure 15 show that the enzyme production begins in mid-log phase of growth and continues into stationary phase, when the organism is grown in $M=9$ medjum with $0.05 \%$ dextrose and supplemented with the amino acids, valine, isoleucine, and phenylalanine.

The fact that enzyme is liberated during logaritmic phase of 
of growth is evidence that the enzyne is extracellular (Pollock, 1962). Both plots in Figure 15, $i, e, l o g$ of cell number and the culture optical density at $660 \mathrm{~nm}$, as related to the proteolytic assay and against time, substantiate that protease production reaches its naximum activity during stationary phase. 
1. The organism requires gool aeration fox enzyme production.

2. The required amino acids and their respective concentrations needed for enzyme production are as follows: $0.5 \mathrm{mg} / \mathrm{mi}$ phenylalanine, 0.05 to $1.0 \mathrm{mg} / \mathrm{m}$. isoleucine, and $2.0 \mathrm{mg} / \mathrm{ml}$ valine. Isoleucine at concentrations greater than $1.0 \mathrm{mg} / \mathrm{ml}$ tend to inhibit active enzyme synthesis.

3. Magnestum at a concentration of $0.01 \mathrm{M}$ fulfills the divalent lon concentration for maximum enzyme formation.

4. Enzyme production is limited when the dextrose concentration is greator than $0.05 \%$, although growth does not appear to be affected.

5. Enzyme production begins during $10 \mathrm{~g}$ phase of growth, and peaks during stationary phase. 
RETERENCES

Bender, J.L., and F.J. Kezdy, 1955. Mechanisis of action of proteolytic enzymes. Annual. Review of Biocheristry. $34: 49$.

Berger, J., M.J. Johson, and W.H. Peterson, 1938,a. The proteolytic enzymes of bacteria. I. The Peptidases of Leucunostoc mesenteroides. Journal of Biological Chenistry. 124:395.

Berger, J., M.J. Johnson, W.H. Peterson. 1938,b. The proteolytic enzymes of bacteria. II. The peptidases of some common bacteria. Iournal of Bacteriology. 36:521.

Bidwel1, E. 1948. The k-toxin (collagense) of Clostridiun welchip. Eiochenjcal Journal. $44: 28$.

Bidwe11, E. 1950. Proteolytic enzymes of Clostridiun welchit. Biochemical Jourral. 46:589.

Bidwe11, E., H.E. van Heyningen, P.A. Char1wood. 1948. The biochemistry of gas gangrene toxins: The k-toxin (collacenase) of clostridium welchii. Biochenical Journal. $42: 140$.

Casas, I.A., and L. M. Zimmermann. 1969. Dependence of protease secretion by Streptococcus faecalis var. liquefaciens on arginine and its possible relation to the site of synthesis. Intrnel of Bacteriology. $97: 307$.

Conn, E.E., and P.K. Stumpf. 1964. Out1ines of Biochemiecty, John Wiley \& Sons, Inc., New York. P. 58-74.

Eagon, R.G. 1968. Advanced General Microbiolory Labosatory Methods. Burgess Publishing Co., Winneapolis, Minn. Pp 25-32.

Evans, D.G. 1943. The production by certain species of Clostridiun of enzymes disintegrating hide powder. Journal of General Microbiology. $\quad 1: 378$.

Fisher, E. Jr. 1960. Some properties of a proteinase obtained from Pseudoronas aerusinosa. Bacteriological Proceedinss. $60: 60$.

Fisher, E. Jr., and J.H. Allen. 1958. Corneal ulcers produced by cell free extracts of Pseudoronas aeruginosa. American Journal of Opthalonology. $46: 21$.

Gallop, P.M., S. Seifter, E. Meilman. 1957. Studies on collagen. I. The partial purification, assay, and mode of activation of bacterial collagenase. Journal of Biological Chemistry. 227-891. 
Jennison, M.W. 1945. Bacterial collagenase. Jounal of Bacteriolozy. $50: 369$.

Kay, W.W. and A.H. Gronlund. 1969. Influence of carbon or nitrogen starvation on amino acid transport in Pseudononas aeruginosa. Journal of Bacteriology. 100:276.

Keen, N.T. and P.H. Williams. 1967. Nfect of nutritional factors on extracellular protease production by Pseudomonas lachrvmans. Canadian Journa1 of Microbiology. 13:0́63.

Kocholaty, W. and I.E. Krejei. 1948, The activation mechanism and physicochemical properties of clostridium histolyticum proteinase. Archives of Biochemistry. 18: 1 .

Litchfield, $C_{0}$.D. and J.M. Prescoti. 1970. Reglilation of proteolytic enzyne production by Aeromonas proteolytica. T. Eztracelluiar endopeptidases. Candian JownaI of Microbiolosy. 16:1\%。

Mandl, I., S. Keller, J. Manahan, 1964. Multiplicity of Clostridium histolvticln coliagnase. Biochenistry. 3:1737.

Harvin, J., W.R. Hearn, J,V. Zyskind, D.J. Tipper, J.I. Stroninger, 1969. Specificity of a bacteliojytic enzyne from Pseudomonas aeruoinosa. Journal of Bacteriology. 100:254.

Maschmann, E. 1938. Uber bacterien proteasen IX. Die anaerobiase der gasbranderreger. Biochenische Zeitschrisk. 297-284.

MeJonald, I.J., A.K. Chambers. 1966. Regulation of proteinase formation in a Micrococcus. Canadian Journal of Microbiology. 12:1175.

Morihara, K, 1963. Pseudomonas aeruginosa proteinase. I. Purification and general properties. Biochimica et Biophysica Acta. 73:113.

Narayanan, E.K., P. Devi, P.S. Menon, 1953. Enzymes of Vibrio cholerae with possible role in pathogenesis. Indian Journal of Medical Research. 41:295.

Norton, J.E. and J.R. Sokatch, 1966, Oxidation of D- and L-valine by enzymes of pseudomonas aeruginosa. Journal of Bacteriology. $92: 116$.

Pataki, G. 1968, Techniques of Thin-layer Chromatorraphy in Anino Acid and Peptide Chemistry. Arn Arbor Science Publishers, Inc. Ann Arbor, Michisan, Pp 65-84.

Pollock, M.R. 1962. Exoenzymes, p. 121-170. In I.C. Gunsalus and R.Y. Stanier (ed.), The Pacteria, vol. IV, Acadenic Press, Nev York.

Sashital, K.S., and L.N. Zimerman, 1968. Catabolite repression and feedback inhibition of protease in streptococcus faecalis var. 
Iiquefaciens. Camadian Journel of Microbinlocy. 14:1265.

Schoelhnam, G., and F. Fisher, Jr. 1966. A collagenase from Pseudomonas aeruinosa. Biochimica et Biophysica Acta. 122:557.

Weifter, S., P.Y. Gallop, L.P. Klein, and E. Meilman, 1959. Studies on collagen. IT. Properties of purified collagenase and its inhibition. Joumal of Biolocical Cheristry. 235:285.

Snith, I. 1958. Chromatograpic Techniques. William Heiniman Medical Books, Itd. Iondor. Pp. 6-35, 59-91.

Sokatch, J.R. 1966. Alanine and aspartate formation during growth on valine $\mathrm{C}^{14}$ by seudoronas aerurinosa.' Journal of Bacteriology. $92: 72$.

Sonkuti, G.t, and F.J. Babe1. 1967. Conditions influencing the synthesis of acid protease by ycor pusjilus Lindt. Apolied Herobiolory. $15: 1309$.

Thinann, $K, V$ 1963. The Ijife of Bacteria. The Macmillan Co. New York. $P_{P} \cdot 293-305$.

Tomare11j, R.M., J. Charney, and $\mathrm{H}_{0} \mathrm{C}$. Harding. 1949. The use of azoalbunin as a substrate in the colorimetric determination of peptic and tryptic activity. Journal of Lahoratory and C1inical. nedicine. $34: 428$. 